\title{
A Review on the Application of Isotopic Techniques to Trace Groundwater Pollution Sources within Developing Countries
}

\author{
Abdul Aziz Sankoh ${ }^{1,2,3, *}$, Nana Sarfo Agyemang Derkyi ${ }^{2,4}$, Ronnie A. D. Frazer-williams ${ }^{3}$, Cynthia Laar 5 \\ and Ishmail Kamara 6
}

check for updates

Citation: Sankoh, A.A.; Derkyi, N.S.A.; Frazer-williams, R.A.D.; Laar,

C.; Kamara, I. A Review on the Application of Isotopic Techniques to Trace Groundwater Pollution Sources within Developing Countries. Water 2022, 14, 35. https://doi.org/ 10.3390/w14010035

Academic Editor: Anas Ghadouani

Received: 12 October 2021

Accepted: 1 December 2021

Published: 24 December 2021

Publisher's Note: MDPI stays neutral with regard to jurisdictional claims in published maps and institutional affiliations.

Copyright: (c) 2021 by the authors. Licensee MDPI, Basel, Switzerland. This article is an open access article distributed under the terms and conditions of the Creative Commons Attribution (CC BY) license (https:// creativecommons.org/licenses/by/ $4.0 /)$.
1 Department of Civil and Environmental Engineering, University of Energy and Natural Resources, Sunyani P.O. Box 214, Ghana

2 Regional Center for Energy and Environmental Sustainability, University of Energy and Natural Resources, Sunyani P.O. Box 214, Ghana; nana.derkyi@uenr.edu.gh

3 Department of Chemistry, Fourah Bay College, University of Sierra Leone, Mount Aureol, Freetown P.O. Box 87, Sierra Leone; ronniefrazerwilliams@gmail.com

4 Department of Energy and Petroleum Engineering, University of Energy and Natural Resources, Sunyani P.O. Box 214, Ghana

5 National Nuclear Research Institute, Ghana Atomic Energy Commission, Legon Accra P.O. Box LG 80, Ghana; c.laar@gaecgh.org

6 National Water Resource Management Agency, King Harman Road, Freetown P.O. Box 778, Sierra Leone; ish83ish@yahoo.com

* Correspondence: aziz_sankoh@yahoo.com

\begin{abstract}
Owing to a lack of efficient solid waste management (SWM) systems, groundwater in most developing countries is found to be contaminated and tends to pose significant environmental health risks. This review paper proffers guidelines on the application of isotopic techniques to trace groundwater pollution sources from data spanning from 2010 to 2020 within developing countries. Earlier groundwater studies in those countries were mainly focused on using hydrochemical and geophysical techniques. The limitation of these techniques is that they can only monitor the concentration of pollutants in the water bodies and possible leachate infiltration but cannot determine the specific sources of the pollution. Stable isotopes of $\delta^{18} \mathrm{O}, \delta^{2} \mathrm{H}$ and $\delta^{13} \mathrm{C}$ can confirm leachate migration to water bodies due to methanogenesis. The high tritium in landfill leachates is useful to identify leachate percolation in groundwater. The $\delta^{15} \mathrm{~N}$ technique has been used to distinguish between synthetic and organic nitrogen sources but its application is limited to differentiating between atmospheric vs. inorganic nitrogen sources. The use of a dual isotope of $\delta^{15} \mathrm{~N}-\mathrm{NO}_{3}^{-}$and $\delta^{18} \mathrm{O}-\mathrm{NO}_{3}^{-}$is beneficial in terms of identifying various sources of nitrogen such as atmospheric and inorganic fertilizers but is yet to be used to differentiate between nitrogen pollution sources from dumpsites, sewage and animal manure. The coupling of the ${ }^{11} \mathrm{~B}$ isotope with $\delta^{15} \mathrm{~N}-\mathrm{NO}_{3}^{-}$and $\delta^{18} \mathrm{O}-\mathrm{NO}_{3}^{-}$and other hydrochemical parameters has proven to be effective in distinguishing between nitrate fertilizer, animal manure, seawater contamination and sewage. Therefore, in areas affected by agricultural activities, landfill leachates, domestic or sewage effluent and seawater intrusion, it is incumbent to couple hydrochemical $\left(\mathrm{Cl}^{-}, \mathrm{NO}_{3}^{-}, \mathrm{B}, \mathrm{DO}\right)$ and isotope techniques $\left(\delta^{18} \mathrm{O},{ }^{2} \mathrm{H}, \delta^{13} \mathrm{C}\right.$, $\delta^{18} \mathrm{O}-\mathrm{NO}_{3}^{-}, \delta^{15} \mathrm{~N}-\mathrm{NO}_{3}^{-}, \delta^{11} \mathrm{~B}$ and $\left.{ }^{3} \mathrm{H}\right)$ to effectively determine pollution sources of groundwater in developing countries. The foregoing review will provide guidelines for studies that may aim to critically distinguish between seawater intrusion, dumpsites, sewage and septic leachates.
\end{abstract}

Keywords: isotope techniques; groundwater pollution; dumpsites; leachate; seawater intrusion

\section{Introduction}

Globally, proper waste disposal is a problem due to increasing population, economic growth and industrialization [1]. The effective management of waste is crucial for sustainable development, but it remains a challenge for most developing countries where over 
$90 \%$ of the waste is disposed in uncontrolled open dumpsites [2]. As a result, around nine million people die each year of diseases linked to pollutants embedded in wastes [2].

The main issues related to open dumpsites involves the increasing pollution of nitrates $\left(\mathrm{NO}_{3}\right)$ in groundwater [3]. High nitrate concentrations affect human health and its consumption can induce methemoglobinemia (blue baby syndrome), cancer and can also augment hypoxia [4]. As a result, the World Health Organization (WHO) and European Union (EU) have set a maximum contaminant limit of $50 \mathrm{mgL}^{-1}$ for $\mathrm{NO}_{3}$ [5]. This concentration is approximately equal to $10 \mathrm{mgL}^{-1} \mathrm{~N}$.

Moreover, groundwater can be contaminated by a wide variety of compounds, which can be natural or anthropogenic. The contamination sources can be grouped into point and nonpoint sources. Point sources occur from a single identifiable point whilst nonpoint sources occur due to various unidentifiable points or linear and areal sources such as: leaching of excessive fertilizers, toxic wastes from dumpsites and seawater intrusion, etc. These make it more difficult to monitor and enforce mitigating controls [6]. It is noteworthy that non-point sources of pollution tend to be the major contaminant sources of groundwater in developing countries. In light of the above, the need for monitoring waterbodies from dumpsites and other sources of contamination is important for any water resource management plan. According to [7], the proper management of groundwater quality requires the identification of the specific pollution sources involved.

Previous groundwater studies by [8-11] in developing countries were mainly focused on using hydrochemical and geophysical data which only determine the concentration of pollutants in water samples and leachates. The principle of geophysical analysis links low resistivity to leachate percolation from dumpsites. This principle is quite vague owing to the fact that there are several pollution sources, such as seawater intrusion and sewage runoffs [9] that may cause low resistivity, and this has led to its limitation in precisely identifying leachate sources. However, with the emergence and use of isotope techniques, researchers have been able to deduce the pollution sources and also provide more definitive indications of the origin of surface and groundwater recharge [12]. Therefore, this review paper summarizes the current state of the use of stable and radioactive isotopes to investigate leachate migration from dumpsites and other sources of microbial contamination. It also emphasizes how the integration of hydrochemical, dual isotopes of $\mathrm{NO}_{3}^{-}$, as well as stable and radioactive isotopes, can be used to identify the various factors impacting groundwater pollution. This review paper also details a summary guide to using isotope methods for the identification of pollution sources.

\section{Overview of Isotope Application in Groundwater Studies}

Stable isotopes and radioactive isotopes have wide applications in hydrological investigations and provide vital information, for example, aquifer-aquifer interconnection, groundwater age and sources of groundwater pollution $[13,14]$. These applications are fundamentally focused on the general principle of tracing. The principle involves the tracking of the movement and transformation of specific substances such as nitrate, chlorinated compounds, carbonate and other anthropogenic compounds from water bodies. Isotope composition is expressed as the ratios in isotope abundances relative to a standard in delta (ठ) notation [5]:

$$
\delta=\left(\frac{\mathrm{R}_{\text {Sample }}}{\mathrm{R}_{\text {Standard }}}-1\right) \times 10^{3},
$$

where:

$\mathrm{R}_{\text {sample }}$ are the heavy (rare) to light (abundant) isotope ratios of the sample;

$\mathrm{R}_{\text {standard }}$ are the heavy (rare) to light (abundant) ratios of the standard.

The most widely used isotopes are oxygen $(\mathrm{O})$, hydrogen $(\mathrm{H})$, carbon $(\mathrm{C})$, sulfur and nitrogen (N) [7]. Environmental isotopes (Table 1) in water bodies and other materials have been widely employed for more than eight (8) decades to advance our knowledge on hydrogeological and environmental processes. 
Table 1. Environment isotopes used for various groundwater studies.

\begin{tabular}{|c|c|c|c|c|c|}
\hline $\begin{array}{l}\text { Element } \\
\text { Symbol }\end{array}$ & Isotope & Ratio & $\begin{array}{l}\% \text { Natural } \\
\text { Abundance }\end{array}$ & Application & References \\
\hline $\mathrm{H}$ & $\delta^{2} \mathrm{H}$ & ${ }^{2} \mathrm{H} /{ }^{1} \mathrm{H}$ & 0.015 & Origin of water & [15] \\
\hline $\mathrm{H}$ & ${ }^{3} \mathrm{H}$ & & $10^{-18}$ & Dumpsite leachate & [16] \\
\hline $\mathrm{N}$ & $\delta^{15} \mathrm{~N}$ & ${ }^{15} \mathrm{~N} /{ }^{14} \mathrm{~N}$ & 0.366 & Source of pollution & [17] \\
\hline $\mathrm{Cl}$ & $\delta^{37} \mathrm{Cl}$ & ${ }^{37} \mathrm{Cl} /{ }^{35} \mathrm{Cl}$ & 24.23 & Origin and transformation of chlorinated compounds & [18] \\
\hline B & $\delta^{11} \mathrm{~B}$ & ${ }^{11} \mathrm{~B} /{ }^{1 \mathrm{o}} \mathrm{B}$ & 80.1 & Anthropogenic and geogenic pollution source & [19] \\
\hline $\mathrm{O}$ & $\delta^{18} \mathrm{O}$ & ${ }^{18} \mathrm{O} /{ }^{16} \mathrm{O}$ & 0.204 & Origin of water & [15] \\
\hline $\mathrm{C}$ & $\delta^{13} \mathrm{C}$ & ${ }^{13} \mathrm{C} /{ }^{12} \mathrm{C}$ & 1.11 & Carbonate source & \\
\hline S & $\delta^{34} S$ & ${ }^{34} \mathrm{~S} /{ }^{32} \mathrm{~S}$ & 4.21 & $\begin{array}{l}\text { Potential sources of sulphate from landfill and acid } \\
\text { mine drainage }\end{array}$ & [7] \\
\hline
\end{tabular}

\subsection{Using Isotopes of $O, H$ and $C$ to Determine Leachate Migration}

The use of water in hydrogeology and environmental studies started in 1935, when the ratios of oxygen isotope $\left({ }^{18} \mathrm{O} /{ }^{16} \mathrm{O}\right)$ were evaluated on the water of Lake Michigan, United States of America [20]. Since then, the application of environmental isotopes in groundwater and surface water studies has demonstrated their importance in terms of better understanding contaminant flow as well as in pollution source identification. Although several studies have used the isotope ratios of $\mathrm{H}$ and $\mathrm{O}$ for hydrologic and geochemical investigations, only a few applications [16,21,22], have been reported for dumpsites in developing countries.

Landfills generate leachate, which contains methane $\left(\mathrm{CH}_{4}\right)$ and carbon dioxide $\left(\mathrm{CO}_{2}\right)$ gas, through a process called methanogenesis [23-25]. Methanogenesis is a process by which microorganisms (methanogens) utilize organic and inorganic compounds to produce $\mathrm{CH}_{4}$ and $\mathrm{CO}_{2}$ under anaerobic conditions $[23,26,27]$. According to $[28,29]$, the microorganisms tend to react more rapidly with lighter isotopes $\left({ }^{1} \mathrm{H}\right)$ of $\mathrm{CH}_{4}$ gas leaving the "heavier" isotope $\left({ }^{2} \mathrm{H}\right)$ in the leachate. Since most of the lighter isotope has already been consumed by microorganisms, the abundant amount of heavier isotopes $\left({ }^{2} \mathrm{H}\right)$ left on the residual $\mathrm{CH}_{4}$ of the leachate will percolate into nearby water bodies within the landfills, causing $\delta^{2} \mathrm{H}$ enrichment of the affected water. On the other hand, though acid fermentation and hydrolysis may cause significant reductions in the oxygen concentration in landfills, they may not cause any variation on the $\delta^{18} \mathrm{O}$ isotope content. This is because $\delta^{18} \mathrm{O}$ isotope fractionation is only influenced by phase changes, such as evaporation and condensation, but is unaffected by biogeochemical reactions [25,26]. Since $\delta^{2} \mathrm{H}$ is enriched whilst $\delta^{18} \mathrm{O}$ is unaffected by methanogenesis, this confirms their usefulness in determining leachate infiltration in groundwater bodies. However, using stable isotopes of $\delta^{18} \mathrm{O}$ and $\delta^{2} \mathrm{H}$ in groundwater pollution studies can only confirm that the waterbodies are being contaminated by leachate migration associated with methanogenesis. The shortcoming of this method is that it cannot depict the exact sources (dumpsites, sewage or animal manures) of the leachates since those sources can significantly induce methane gas. Thus, the combination of tritium and stable isotopes $\left(\delta^{18} \mathrm{O}\right.$ and $\left.\delta^{2} \mathrm{H}\right)$ can be used to determine the sources of leachates.

The authors of $[16,21,22]$ employed stable and radioactive isotopes of water to verify the migration of leachate contaminant in the water bodies of Bantar Gebang Landfill, Indonesia, Metro Manila, Philippines and Andralanitra landfill site, Madagascar, respectively. To confirm the interaction of leachate with groundwater bodies, the stable isotope compositions of the leachates and those of the monitoring wells were measured and the results are presented in Table 2 and Figure 1, respectively.

The ${ }^{2} \mathrm{H}$ values of the leachates were relatively highly enriched ( +6 to $+16 \%$ ), whilst $\delta^{18} \mathrm{O}$ is depleted and ranged from -4.5 to $-3.7 \%$ [21]. Similarly, studies by $[23,24]$ reported highly enriched $\delta^{2} \mathrm{H}$ values ranging from +30 to $+60 \%$ in landfill leachates with respect to local average precipitation values, and these were associated with methanogenesis. The deuterium enrichment $(-3.6$ to $+10.3 \%$ ) and depletion $(-21.87$ to $+7.86 \%$ of leachates 
during the dry and rainy season, respectively, were also observed (Table 2). In Figure 1a, the isotopic values $\left(\delta^{2} \mathrm{H}\right.$ and $\left.\delta^{18} \mathrm{O}\right)$ of water in the drier months were below the Local Meteoric Water Line (LMWL) but fell above the LWML during the rainy season, especially for well 3 and 4 , owing to increased deuterium concentrations. The forgoing deuterium enrichment seasonal pattern observed in groundwater was attributed to leachate infiltration from the landfill through fractures in the underlying rocks $[25,26]$.

Table 2. Isotope data of leachate and monitoring well.

\begin{tabular}{llllll}
\hline $\begin{array}{l}\text { Sample } \\
\text { Code }\end{array}$ & Sample Type & $\begin{array}{l}\mathcal{\delta}^{2} \mathbf{H}(\mathbf{\%}) \\
\text { Dry } \\
\text { Rainy }\end{array}$ & $\begin{array}{l}\mathcal{\delta}^{18} \mathbf{O}(\%) \\
\text { Dry } \\
\text { Rainy }\end{array}$ & ${ }^{3} \mathbf{H}$ (TU) & Reference \\
\hline BG-LA & Outlet and inlet leachate & -3.6 to +10.3 & -0.42 to 0.67 & 50.9 to 493.9 & {$[16]$} \\
& & -21.87 to +7.86 & -5.93 to -5.43 & \\
BG-MA & Monitoring well down-gradient of & -37.9 to -30.6 & -6.26 to -5.81 & 14.9 to 76.7 \\
& Plant A & -37.42 to -29.80 & -6.02 to -5.96 & \\
\hline
\end{tabular}

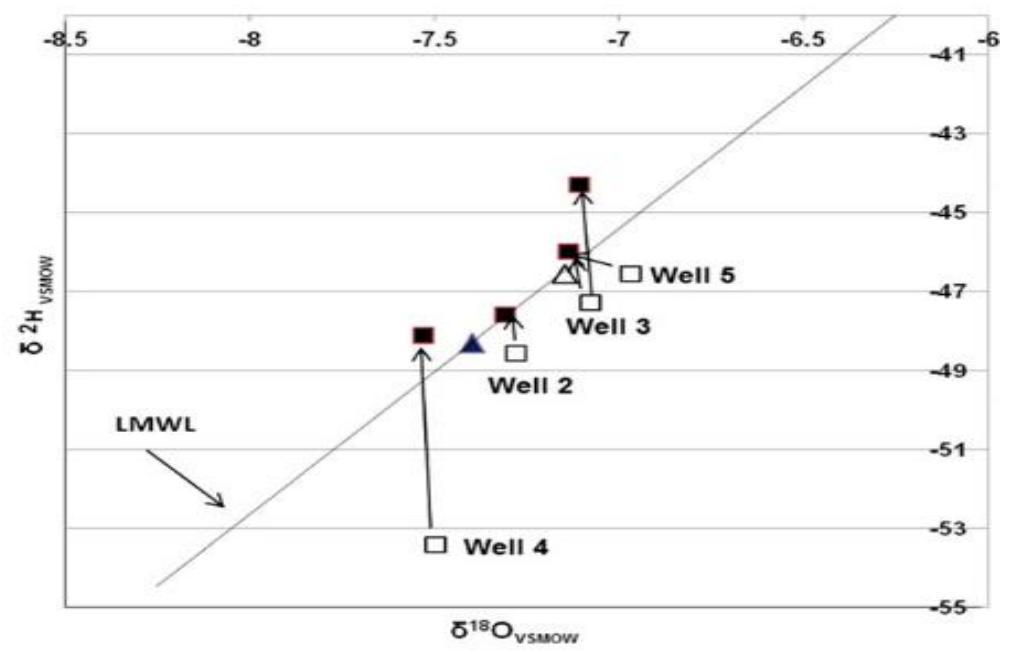

(a)

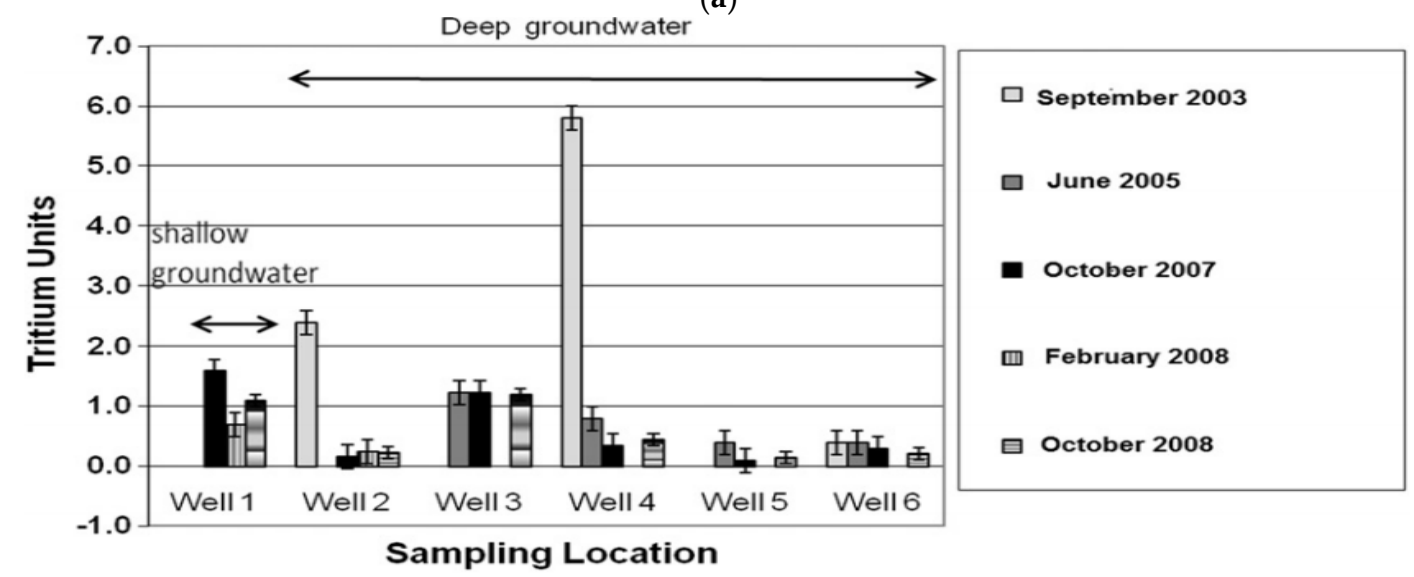

(b)

Figure 1. (a). Deuterium and oxygen 18 deviation from rainy to dry season [21]. (b). Tritium trends from 2003 to 2008 of groundwater within the Rodriguez municipality, immediately downstream of the landfills [21].

Tritium concentrations were measured in groundwater, landfill leachates, precipitation and surface water at the above-mentioned sites. The conservative nature and low detection levels of tritium enable its wide application as a pollution tracer in groundwater studies $[30,31]$. Tritium isotope is naturally produced in the atmosphere at a very 
low rate through the reaction of oxygen atoms and high-energy cosmic radiation. The produced tritium is subsequently oxidized to titrated water (THO), and thus, enters the hydrological cycle in precipitation [32,33]. The treatment of landfill leachates via evaporation (burning) converts the tritium in the titrated methane (present in the landfill gas) to tritiated water vapor.

The trend in tritium concentrations of groundwater immediately downstream of the landfill in Metro Manila, Philippines, is presented in Figure 1b. The mean value for tritium precipitation within the study area was assumed to be $1.9 \mathrm{TU}$ [21]. Thus, any groundwater values above the mean precipitation value were likely inferred to have been impacted by other anthropogenic sources of tritium within the landfill. Even though high tritium values $(>2000 \mathrm{TU})$ resulted from the atmospheric thermonuclear testing between 1952 and 1963 [34], these values decayed from 2000 to $20 \mathrm{TU}$ (Canada) and from 4000 to $10 \mathrm{TU}$ (UK), the same levels at the year 1985 [30]. This is clear evidence that the high tritium concentration in modern precipitation and groundwater may not be primarily an effect of the nuclear bomb testing, but mainly a result of atmospheric deposition of high energy cosmic rays and landfill leachate. Landfill leachate was detected to contain elevated tritium concentration as far back as 1982 [35]. In the current review study, the tritium value in the leachate ranged from 50.9 to 493.9 TU (Table 2) in plant A of Bantar Gebang Landfill, Indonesia. Several studies $[30,33,36]$ have established that landfills leachates contain elevated tritium in the range of $6440 \mathrm{TU}(760 \mathrm{~Bq} / \mathrm{L})$ (Australia), 10,000 TU (UK) and $159,316 \mathrm{TU}(513,000 \mathrm{pCi} / \mathrm{L})$ (USA). The elevated tritium concentration in landfill leachates according to $[33,34]$ is associated with luminescent dial-plates of watches, gaseous tritium light sources (GTLS), trimphone, clocks, luminous paint, key chains and hospital products deposited in landfills. These sources, especially GTLS, can induce up to $6.6 \times 10^{9} \mathrm{TU}$ (7.5GBq) [33]; exit signs have up to 30 curies of tritium [36]. GTLS are mostly used in developed countries but are apparently deposited into municipal solid waste in developing countries. The tritium concentrations in the shallow groundwater (Well 1) during the end of the rainy season (October, 2007) match with those of the precipitation tritium values (Figure 1b), thus indicating the immediate infiltration of rainfall. Even though groundwater is expected to contain little or no tritium, wells 2 and 4 in the peak of the rainy season (September, 2003) contain elevated tritium concentrations of $2.3 \pm 0.5$ and $5.8 \pm 0.4 \mathrm{TU}$, respectively (Figure $1 \mathrm{~b}$ ), above the mean precipitation value (1.9 TU). This may be due to direct infiltration of leachate from the landfill of the underlying aquifer through the fractured rocks. Furthermore, elevated tritium contents ranging from 14.9 to $76.6 \mathrm{TU}$ (Table 2) and 10.4 to $22.8 \mathrm{TU}$ (Table 3) were also observed in groundwater that was downgradient to landfills.

Table 3. Isotope data of hand-dug wells.

\begin{tabular}{|c|c|c|c|c|c|}
\hline $\begin{array}{l}\text { Sample } \\
\text { Code }\end{array}$ & Sample Type & $\begin{array}{l}\delta^{2} \mathbf{H} \\
(\%)\end{array}$ & $\begin{array}{l}\delta^{18} \mathrm{O} \\
(\% \text { o) }\end{array}$ & $\begin{array}{l}{ }^{3} \mathrm{H} \\
(\mathrm{TU})\end{array}$ & Reference \\
\hline Group 1 & $\begin{array}{l}\text { Hand-dug well down-gradient of the } \\
\text { landfill }\end{array}$ & -42.80 to -40.77 & -6.81 to -6.63 & 10.4 to 22.8 & [22] \\
\hline Group 2 & $\begin{array}{l}\text { Hand-dug well upstream and } 700 \mathrm{~m} \\
\text { downstream from landfills }\end{array}$ & -46.63 to -39.12 & -7.51 to -5.91 & $0.84-1.46$ & \\
\hline
\end{tabular}

Conversely, the monitoring of wells that are upstream and also those that are $700 \mathrm{~m}$ away downstream from landfills showed depleted tritium contents of 0.84 to $1.46 \mathrm{TU}$, as evidenced in Table 2 [22]. This is congruent with the study of [21] where the deep groundwater wells 5 and 6 , which are farther away from the landfill had very low tritium concentrations ( 0 to $0.4 \mathrm{TU}$ ) throughout the period. The preceding trend may be due to the limited impact of the leachate to those wells, as evidenced by an increased distance. The authors of [30] reported decreased tritium values on wells that are located away from dumpsites and trenches.

The use of tritium content as a leachate tracer is predominantly effective; it is not present in seawater nor fertilizers and, thus, provides a basis for distinguishing groundwa- 
ter and leachates. These peculiarities make it preferable to any chemical and other isotopic parameters to delineate dumpsite leachates from septic waste and fertilizers. However, no technique can be $100 \%$ effective in all cases; e.g., there have been scenarios in which water bodies can contain enriched deuterium and negligible tritium values in waterbodies closer to landfills, as observed in Table 3 [37]. This may be due to the following reasons: (1) there could have been leachate percolation, but materials containing tritium had not been deposited in the landfills; (2) the landfills might be very old, causing substantial decay, or very new, with low tritium-enrichment; (3) a lack of leachate percolation but rapid evaporation may have triggered the deuterium enrichment. The latter (3) is mainly observed in rivers or lakes as they are more exposed to sunlight leading to rapid evaporation. There have also been situations where tritium production is linked to other anthropogenic activities such as nuclear plants and, thus, no enrichment of deuterium was observed. Therefore, to effectively confirm the infiltration of landfill leachates into waterbodies, there is a need to integrate ${ }^{13} \mathrm{C}$ isotope owing to its being unaffected by condensation and evaporation, but only by the occurrence of microorganisms and organic matter.

The contribution of carbon to different pollutant sources makes it possible to assess the impact of carbon (C) in the environment [38]. The unique isotopic composition of carbon in groundwater and leachate proffers invaluable understandings of the $\mathrm{C}$ transfer between natural environment and landfills. All water has some amount of inorganic $C$ dissolved in solution, which is referred to as dissolved inorganic carbon (DIC). DIC comprises the carbonate ion $\left(\mathrm{CO}_{3}^{2-}\right)$, the bicarbonate ion $\left(\mathrm{HCO}_{3}^{-}\right)$, and aqueous carbon dioxide [39]. The isotopic composition of DIC $\left(\delta^{13} \mathrm{C}_{\mathrm{DIC}}\right)$ derived from organic matter decomposition is $-28 \%$ [38]. However, the $\delta^{13} \mathrm{C}_{\mathrm{DIC}}$ from calcite dissolution and other carbonate minerals fall within the range of -14.6 to $+1.1 \%$ whilst the isotopic signature of the diffusing $\mathrm{CO}_{2}$ is approximately $-8 \%$ [38].

In landfills, methanogenesis may trigger the production of methane and $\mathrm{CO}_{2(\mathrm{~g})}$. Owing to the presence of sufficient microorganisms within the leachate of landfills, substantial amounts of the lighter isotope, ${ }^{12} \mathrm{C}$, of the dissolved inorganic carbon $\left(\mathrm{CO}_{2}\right)$ will be used up, thus leaving exorbitant amounts of the heavier isotope, ${ }^{13} \mathrm{C}$, in the residual $\mathrm{CO}_{2}$ of the leachate pool. Therefore, the $\delta^{13} \mathrm{C}$-DIC of leachate-contaminated groundwater will be highly enriched, ranging from $+10 \%$ [ [23] to $+38 \%$ [ [38,40]; the variation depends on the landfill activity [38]. Within developing countries, researchers including [25,37] employed $\delta^{2} \mathrm{H}, \delta^{18} \mathrm{O}$ and $\delta^{13} \mathrm{C}$ to identify leachate-contaminated groundwater in the vicinity of landfills and the results are shown in Table 4.

Table 4. Isotope data of hand-dug wells, stream, and leachate samples.

\begin{tabular}{|c|c|c|c|c|c|c|}
\hline $\begin{array}{l}\text { Sample } \\
\text { Code }\end{array}$ & $\begin{array}{l}\text { Sample } \\
\text { Type }\end{array}$ & Comment & $\begin{array}{l}\delta^{2} \mathbf{H} \\
(\%)\end{array}$ & $\begin{array}{l}\delta^{18} \mathrm{O} \\
(\% \text { o) }\end{array}$ & $\begin{array}{l}\delta^{13} C \\
(\%)\end{array}$ & Reference \\
\hline L1-6 & Leachate & Leachate of landfill sites & -38 to -24 & -7.5 to -7.3 & +16.5 to +21.2 & [25] \\
\hline GR1 & Well & Up-gradient to landfill & -38.3 to -35.5 & -5.93 to -5.46 & -14.2 to -12.2 & [37] \\
\hline GW 6 & Well & $\begin{array}{l}\text { Just down-gradient to GW9 and } \\
\text { adjacent to SW1 }\end{array}$ & -42 & -7.0 & +8.9 & [25] \\
\hline GR10 & Stream & Far down-gradient to AKL & -6.3 & +0.71 & +8.97 & [37] \\
\hline GW8 & Well & Just down-gradient of Leachate & -35 & -6.9 & +11.6 & [25] \\
\hline GR9 & Well & Just down-gradient to CKL & -37.0 & -6.17 & -3.3 & [37] \\
\hline
\end{tabular}

The $\delta^{13} \mathrm{C}$-DIC and $\delta^{2} \mathrm{H}$ values of the leachates ranged from +16.5 to $+21.2 \%$ and -38 to $-24 \%$, respectively (Table 4 ). These values compare well with the $\delta^{13} \mathrm{C}-\mathrm{DIC}$ and $\delta^{2} \mathrm{H}$ results of leachate reported by [29] due to the biodegradation of organic matter. Comparatively, the $\delta^{13} \mathrm{C}$-DIC of the downstream water was more enriched than the upstream water, suggesting that the leachate may have interacted with the downstream water [29]. Moreover, $\delta^{13} \mathrm{C}-\mathrm{DIC}$ in the GR1 sample $(-14$ to $-12.2 \%$ ) depicts values that are characteristic of superficial stream water, which may have resulted from carbonate minerals dissolution in the aquifers [38]. Furthermore, well GW6 has depleted deuterium values $\left(-42 \%\right.$ ) and slightly enriched $\delta^{13} \mathrm{C}$ values $\left(+8.9 \%\right.$ ). The depleted $\delta^{2} \mathrm{H}$ isotopic values for 
GW6 might be due to one of two reasons: (i) a decrease in methanogenic activity due to the depletion of organic matter sources [38]; and/or (ii) the interaction of the groundwater and SW1 stream water [29]. Comparatively, both GW6 (Well) and GR10 (stream) have similar ${ }^{13} \mathrm{C}$ values but the latter have enriched $\delta^{2} \mathrm{H}$ and $\delta^{18} \mathrm{O}$. This might be due to the evaporation effect often observed in stream waters. In addition, the $\delta^{13} \mathrm{C}$ values for GW8 are enriched $(+11 \%$ o ) whilst GW9 is $+5 \%$; this is because GW8 occurs immediately downgradient of the landfill whilst GW9 occurs slightly downgradient of GW8. This is one of the main reasons why both have comparable $\delta^{2} \mathrm{H}$ values $(-35 \%$ \& $-34 \%$ o ) as both are from the same recharge source. From the foregoing trend, it could be ascertained that $\delta^{13} \mathrm{C}$ values decrease relative to the increase in distance from landfills.

\subsection{Application of Dual Isotopes of $\delta^{15} N$ and $\delta^{18} O$ and $\delta^{11} B$ to Identify Nitrate Pollution Sources}

Groundwater can be polluted both naturally and anthropogenically by various distinct sources, notably the leaching of excessive fertilizers, the uncontrolled release of toxic wastes from dumpsites, the leaching of sewage waste from neighboring cesspits, and seawater intrusion. All of the foregoing sources except the latter (seawater intrusion) can induce nitrates with different isotopic compositions. Therefore, using an isotopic approach to identify these nitrate sources is vital and should be the first step in deducing the sources of groundwater contamination.

Nitrogen, which has been extensively used to monitor the fate and source of nitrate contaminants, has two isotopes, $\delta^{14} \mathrm{~N}$ and $\delta^{15} \mathrm{~N}$, with relative abundances of $99.63 \%$ and $0.37 \%$, respectively. The principle is that $\mathrm{NO}_{3}^{-}$originating from distinct sources will show different isotope fingerprints.

The nitrogen isotope ratio values were first utilized to deduce the sources of nitrate contamination in the 1970s. The authors of [41] used the foregoing technique to evaluate the contribution of fertilizer to $\mathrm{NO}_{3}^{-}$in the Sangamon River, United States of America. Their research laid the foundation for a stable isotope approach to delineate the various sources of $\mathrm{NO}_{3}^{-}$pollution in water bodies. Understanding the factors that affect the isotopic composition of $\mathrm{N}$ and $\mathrm{O}$ is vital when utilizing the $\delta^{15} \mathrm{~N}$ and $\delta^{18} \mathrm{O}$ technique to determine the sources of nitrates in freshwater bodies. There are several sources of nitrate to waterbodies, some of which are derived from agricultural and industrial activities. The primary microbially mediated reactions that control the dynamics of nitrogen in soil and groundwater are ammonia volatilization, denitrification and nitrification (Figure 2). Both ammonia volatilization and denitrification can significantly increase the $\delta^{15} \mathrm{~N}$ of the residual nitrate in groundwater.

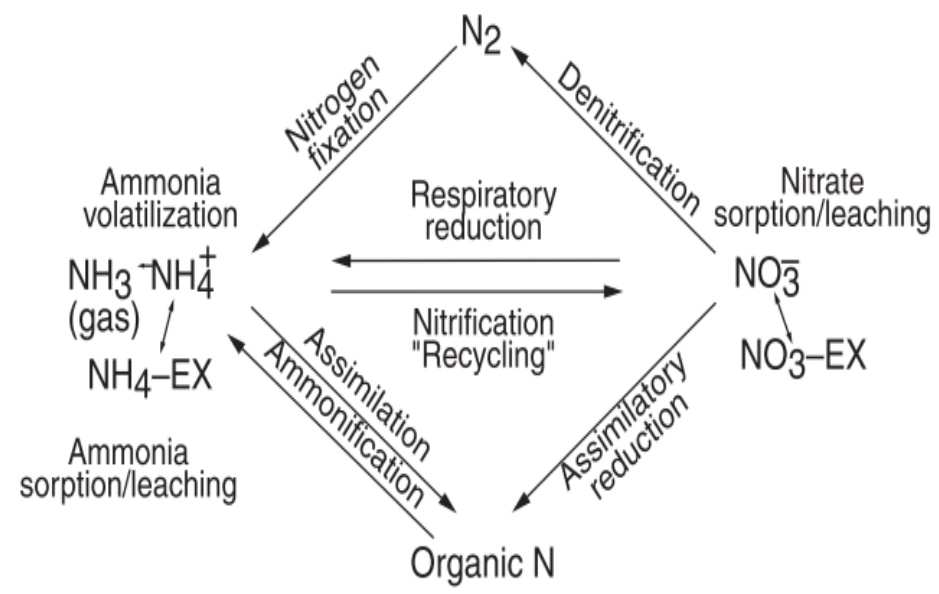

Figure 2. Biochemical cycles of nitrogen [42].

\subsection{Application of $\delta^{15} N$ and $\delta^{18} \mathrm{O}$ to Identify Nitrate Pollution Sources}

Recent studies by [43-45] that utilized nitrogen isotopes to investigate the sources of $\mathrm{NO}_{3}^{-}$have been documented. In spite of its successful application to discriminate $\mathrm{NO}_{3}^{-}$ pollution sources, the $\delta^{15} \mathrm{~N}$ technique still faces some challenges such as other sources 
(atmospheric versus soil nitrate, inorganic fertilizer versus soil nitrate and manure versus landfill waste) not being able to be distinguished due to the intricacies of the various nitrogen transformations that cause overlaps of the $\delta^{15} \mathrm{~N}$. The oxygen isotopes in nitrate $\left(\delta^{18} \mathrm{O}-\mathrm{NO}_{3}\right)$ were employed to lessen the uncertainty of $\delta^{15} \mathrm{~N}-\mathrm{NO}_{3}$. However, $\delta^{18} \mathrm{O}-$ $\mathrm{NO}_{3}$ data have its own complications due to the overlap of their values for nitrate sources from ammonium fertilizer, soil nitrogen, manure and septic wastes, etc. This leads to the conclusion that $\delta^{18} \mathrm{O}-\mathrm{NO}_{3}$ is of little importance in identifying nitrate sources [46].

Owing to the difficulties in distinguishing between the various nitrogen sources mentioned above, the authors of [47] coupled $\delta^{18} \mathrm{O}$ with $\delta^{15} \mathrm{~N}$ to form a dual isotope of $\delta^{18} \mathrm{O}-\mathrm{NO}_{3}$ and $\delta^{15} \mathrm{~N}-\mathrm{NO}_{3}$ to effectively identify the source (s) of nitrate. This dual stable isotope method has been widely utilized to trace nitrate sources in waterbodies by delineating their specific $\delta^{18} \mathrm{O}-\mathrm{NO}_{3}$ and $\delta^{15} \mathrm{~N}-\mathrm{NO}_{3}$ fingerprints.

\subsection{1. $\delta^{15} \mathrm{~N}$ and $\delta^{18} \mathrm{O}$ Fingerprint of Manure and Septic Waste Nitrate sources}

Waste from septic tanks, landfills, animal manure, sludge and sewage contains organic nitrogen, notably urea, as well as organic nitrate, etc. However, these organic nitrogen species have the tendency to transform to other forms of nitrogen via microbial processes known as denitrification and also by ammonification. During these transformational processes, there is significant enrichment of $\delta^{15} \mathrm{~N}-\mathrm{NO}_{3}$ and $\delta^{18} \mathrm{O}-\mathrm{NO}_{3}$. Recent studies (2010 to 2020) in developing countries from selected continents (Asia, Africa, Europe and America) that utilized $\delta^{18} \mathrm{O}-\mathrm{NO}_{3}$ and $\delta^{15} \mathrm{~N}-\mathrm{NO}_{3}$ to investigate the sources of $\mathrm{NO}_{3}^{-}$have been recorded. The authors of [48] utilized $\delta^{18} \mathrm{O}-\mathrm{NO}_{3}$ and $\delta^{15} \mathrm{~N}-\mathrm{NO}_{3}$ to determine the nitrate sources of groundwater in Kano Plains and Kisumu City, Kenya. The $\delta^{15} \mathrm{~N}-\mathrm{NO}_{3}$ concentrations of the boreholes of Kano Plains and Kisumu City ranged from +4.1 to $+25.8 \%$ o for the wet season whilst those of the dry season ranged from +12.4 to $+51.8 \%$. On the other hand, the $\delta^{18} \mathrm{O}-\mathrm{NO}_{3}$ values ranged from -2.4 to $+20.8 \%$ for the wet season and from -1.7 to $+24.1 \%$ for the dry season. Most of these $\delta^{15} \mathrm{~N}-\mathrm{NO}_{3}$ values $(+10$ to $+51.8 \%$ o $)$ partly fell within the range of sewage and animal manure. Considering the effect of seasonality, the $\delta^{15} \mathrm{~N}-\mathrm{NO}_{3}$ and $\delta^{18} \mathrm{O}-\mathrm{NO}_{3}$ values were more enriched in the dry season than the rainy season and this is consistent with the observations of [49]. The enriched isotope values in the drier months could be associated with the enhanced denitrification or volatilization of animal manure triggered by evaporation.

Denitrification is a multiple-step process involving the bacterially mediated reduction of $\mathrm{NO}_{3}^{-}$to nitrous oxide $\left(\mathrm{N}_{2} \mathrm{O}\right)$ and dinitrogen $\left(\mathrm{N}_{2}\right)$ under anoxic condition. It is a redox process where $\mathrm{NO}_{3}^{-}$is used by certain bacteria that act as electron acceptors during the degradation of organic matter (electron donors), producing $\mathrm{N}_{2} \mathrm{O}$ and $\mathrm{N}_{2}$ [50]. Its isotopic fractionation depends on the enrichment of the electron donors, electron acceptor and oxygen concentration. Denitrification can be heterotrophic if linked to the oxidation of organic matter (Equation (2)) or autotrophic if related to the oxidation of inorganic compounds (Equation (3))

$$
\begin{gathered}
4 \mathrm{NO}_{3}^{-}+5 \mathrm{CH}_{2} \mathrm{O} \rightarrow 2 \mathrm{~N}_{2}+4 \mathrm{HCO}_{3}^{-}+\mathrm{CO}_{2}+3 \mathrm{H}_{2} \mathrm{O} \\
14 \mathrm{NO}_{3}^{-}+5 \mathrm{FeS}_{2}+4 \mathrm{H}^{+} \rightarrow 7 \mathrm{~N}_{2}+10 \mathrm{SO}_{4}^{2-}+5 \mathrm{Fe}^{2+}+2 \mathrm{H}_{2} \mathrm{O}
\end{gathered}
$$

During denitrification, bacteria (cyanobacteria) preferentially use lighter isotopes, leading to enriched heavier isotopes in the residual $\mathrm{NO}_{3}^{-}$[51]. However, the presence of algae (benthic algae, which are readily degradable, serving as both $\mathrm{NO}_{3}^{-}$and organic source) may facilitate the denitrification process [52]. Denitrification may drive the values of $\delta^{15} \mathrm{~N}$ from +6 to $+25 \%$ [50]. Because denitrification also causes the fractionation of oxygen-stable isotopes in $\mathrm{NO}_{3}^{-}$, both the $\delta^{15} \mathrm{~N}$ and $\delta^{18} \mathrm{O}$ values of the residual $\mathrm{NO}_{3}^{-}$will increase at a ratio of 1.3:1 to 2:1 (Figure 3) $[48,53]$ and, thus, produce a slope of about 0.5 . 


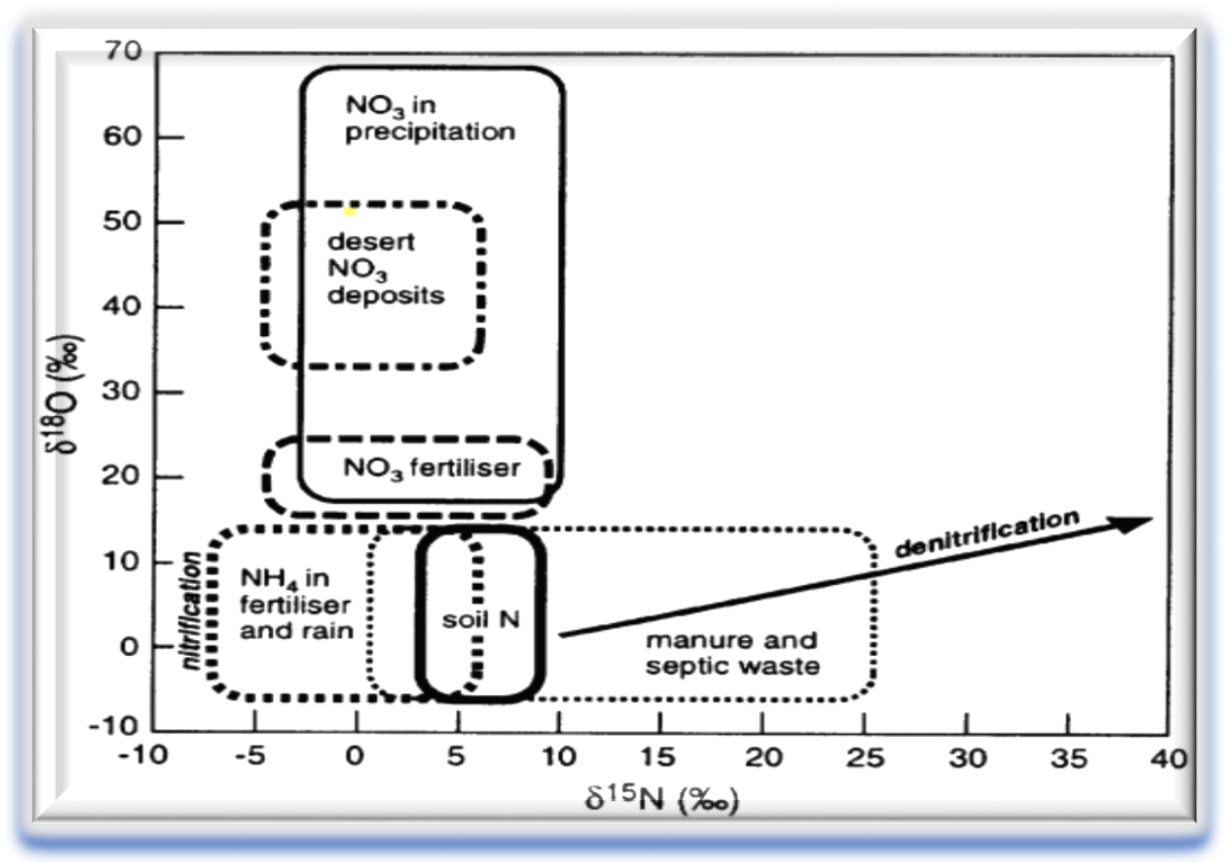

Figure 3. Typical values of $\delta^{15} \mathrm{~N}$ and $\delta^{18} \mathrm{O}$ of nitrate derived from various $\mathrm{N}$ sources [54].

On the other hand, since denitrification involves the reduction of $\mathrm{NO}_{3}^{-}$(terminal electron acceptor) to $\mathrm{N}_{2}$, the concentration of the residual $\mathrm{NO}_{3}^{-}$will be negligible compared to that of the substrate pool. Therefore, increase in denitrification will lead to an increase in $\delta^{15} \mathrm{~N}$ and $\delta^{18} \mathrm{O}$ values with an exponential decrease in nitrate concentration. This observation is, in principle, congruent with the study of [55] where samples taken from farming and animal-rearing areas as well as bad sanitary zones in Ghana had enriched $\delta^{15} \mathrm{~N}-\mathrm{NO}_{3}$ and $\delta^{18} \mathrm{O}-\mathrm{NO}_{3}$ (in the ratio of 2:1) values with a corresponding decrease in $\mathrm{NO}_{3}^{-}$concentration due to the denitrification effect.

Apparently, since denitrification mostly takes place in anoxic conditions, the dissolved oxygen values decrease, ranging between 0 and $0.5 \mathrm{mg} / \mathrm{L}$ [54]. The authors of [53] employed a dual isotope of $\delta^{15} \mathrm{~N}-\mathrm{NO}_{3}$ and $\delta^{18} \mathrm{O}-\mathrm{NO}_{3}$ to probe the sources of $\mathrm{NO}_{3}^{-}$in groundwater in the Turpan-Hami Area, Northern China. The $\delta^{15} \mathrm{~N}-\mathrm{NO}_{3}$ and $\delta^{18} \mathrm{O}-\mathrm{NO}_{3}$ values, respectively, ranged from -0.6 to $31 \%$ and from +16.3 to $+37.4 \%$ and, thus, it was inferred that the $\mathrm{NO}_{3}^{-}$mainly originated from precipitation and denitrification. However, most of the samples displaying denitrification effects had dissolved oxygen values $>2$ $\mathrm{mg} / \mathrm{L}$, which may not be relevant for denitrification. A similar finding was reported in Mexico [49]. On the contrary, the foregoing assertion may not always be true as other studies, conducted elsewhere, suggested that certain bacteria can trigger denitrification in oxygenated environments where there is oxygen fluctuation, such as sandy permeable terrain $[56,57]$. For example, the Paracoccus denitrificans bacteria can induce denitrification under both oxic and anoxic conditions. Therefore, relying on the dissolved oxygen content to ascertain denitrification is quite vague and may be misleading. The other alternative route in which organic nitrogen can be transformed to inorganic nitrogen is through the process known as ammonia volatilization (Equation (4)). Ammonia volatilization is defined as a chemical process that occurs at the surface of the soil when urea fertilizer is converted to $\mathrm{NH}_{3(\mathrm{~g})}$ at high $\mathrm{pH}$. The nitrogen in human excreta predominantly occurs in the form of urea. The urea is hydrolyzed to $\mathrm{NH}_{3}$ and converted to ammonium ion $\left(\mathrm{NH}_{4}^{+}\right)$and $\mathrm{NO}_{3}^{-}$as illustrated below:

$$
\mathrm{CO}\left(\mathrm{NH}_{2}\right)_{2} \rightarrow \mathrm{NH}_{3} \leftrightharpoons \mathrm{NH}_{4}^{+} \rightarrow \mathrm{NO}_{3}^{-}
$$

The hydrolysis of urea triggers an increase in $\mathrm{pH}$ and the produced $\mathrm{NH}_{3}$ is easily lost by volatilization and thus depleted in $\delta^{15} \mathrm{~N}$, while the residual $\mathrm{NH}_{4}^{+}$is highly enriched in $\delta^{15} \mathrm{~N}$. Since a significant proportion of the $\mathrm{NH}_{4}^{+}$is converted into nitrate, the residual $\mathrm{NO}_{3}^{-}$ 
will be highly enriched with $\delta^{15} \mathrm{~N}$. Hence, $\mathrm{NO}_{3}^{-}$originating from animal manure displays $\delta^{15} \mathrm{~N}$ values that are specifically in the range +10 to $+20 \%$ [ [44] and +5 to $+25 \%$ [58].

\subsection{2. $\delta^{15} \mathrm{~N}$ and $\delta^{18} \mathrm{O}$ Fingerprint of Ammonia in Fertilizer and Precipitation}

The indiscriminate and non-strategic use of fertilizers in agriculture results in the increased $\mathrm{NO}_{3}^{-}$concentration of groundwater bodies. Synthetic nitrogen fertilizers, which include commonly applied man-made urea, potassium nitrate $\left(\mathrm{KNO}_{3}\right)$ and ammonium nitrate $\left(\mathrm{NH}_{4} \mathrm{NO}_{3}\right)$, are produced via the fixation of atmospheric nitrogen $\left(\mathrm{N}_{2}\right)$. These anthropogenic fertilizers have ${ }^{15} \mathrm{~N}$ fingerprints ranging from -4 to $+4 \%$, typical of atmospheric nitrogen sources (Figure 3). However, some nitrate fertilizers showed enriched $\delta^{15} \mathrm{~N}$ fingerprints ranging from -8 to $+7 \%$ due to the effect of nitrification.

Nitrification is a process by which $\mathrm{NH}_{4}^{+}$(mediated by distinct autotrophic bacteria) is oxidized into $\mathrm{NO}_{3}^{-}$. Nitrification occurs when biota's $\mathrm{N}$-demand is less than the $\mathrm{NH}_{4}^{+}$ pool and, thus, causes $\mathrm{NO}_{3}^{-}$to leach into the soil horizons and subsequently into water bodies [59]. The mechanism of nitrification occurs in several steps. The steps involve the oxidation of $\mathrm{NH}_{4}^{+}$to $\mathrm{NO}_{2}^{-}$, and subsequent oxidation to $\mathrm{NO}_{3}^{-}$in aerobic conditions (Equation (5)). The nitrogen sources that can undergo nitrification are inorganic fertilizer and soil organic $\mathrm{N}$.

Nitrification Reaction:

$$
\begin{aligned}
& \text { Organic-N } \rightarrow \mathrm{NH}_{4}^{+} \\
& \mathrm{NH}_{4}^{+}+\mathrm{H}_{2} \mathrm{O} \rightarrow \mathrm{NH}_{2} \mathrm{OH}+2[\mathrm{H}]+\mathrm{H}^{+} \\
& \mathrm{NH}_{2} \mathrm{OH}+\mathrm{O}_{2} \rightarrow \mathrm{NO}_{2}^{-}+[\mathrm{H}]+\mathrm{H}^{+} \\
& \mathrm{NO}_{2}^{-}+\mathrm{H}_{2} \mathrm{O} \leftarrow \rightarrow \mathrm{NO}_{3}^{-}+2[\mathrm{H}]
\end{aligned}
$$

The whole nitrification processes involve distinct nitrogen $(\mathrm{N})$ isotopic fractionations, which induce depletion of $\delta^{15} \mathrm{~N}-\mathrm{NO}_{3}$ values in the residual pool. The most significant fractionation step is linked with the transformation of $\mathrm{NH}_{4}^{+}$to $\mathrm{NO}_{2}^{-}$. Generally, the degree of isotope nitrogen fractionation depends on the amount of $\mathrm{NH}_{4}^{+}$ion in the substrate pool. However, the rate of nitrification decreases as the $\mathrm{NH}_{4}^{+}$pool is consumed, causing an insignificant $\mathrm{N}$ fractionation and a small $\delta^{15} \mathrm{~N}$ enrichment in $\mathrm{NO}_{3}^{-}$. Furthermore, nitrogen fractionations are negligible in $\mathrm{N}$-limited systems [60]. With regard to $\delta^{18} \mathrm{O}-\mathrm{NO}_{3}$, several isotope studies demonstrated that $\mathrm{NO}_{3}^{-}$produced by nitrification obtains two oxygen atoms $(\mathrm{O})$ from water molecules and one $\mathrm{O}$ atom from the atmosphere [61,62]. Therefore, the $\delta^{18} \mathrm{O}$ of microbial nitrate can be calculated using Equation (6) if the $\delta^{18} \mathrm{O}$ of water and that of atmospheric $\mathrm{O}_{2}$ are known.

$$
\delta^{18} \mathrm{O}_{\left(\mathrm{NO}_{3}\right)}=\frac{2}{3} \delta^{18} \mathrm{O}_{\left(\mathrm{H}_{2} \mathrm{O}\right)}+\frac{1}{3} \delta^{18} \mathrm{O}_{\left(\mathrm{O}_{2}\right)}
$$

The authors of [63] estimated the $\delta^{18} \mathrm{O}$ of atmospheric $\mathrm{O}_{2}$ to be $23.9 \%$ whilst the $\delta^{18} \mathrm{O}$ of the water molecule could be obtained from the laboratory. For waters with $\delta^{18} \mathrm{O}$ values of -25 to $+4 \%$, the ${ }^{18} \mathrm{O}-\mathrm{NO}_{3}$, formed from ammonium nitrification will range from -10 to $+10 \%$ (Figure 3 ). It is noteworthy that the measured $\delta^{18} \mathrm{O}$ values of microbially produced $\mathrm{NO}_{3}^{-}$can be $5 \%$ higher than the calculated values $[64,65]$.

Conversely, Synthetic $\mathrm{NO}_{3}^{-}$fertilizer is not produced by this same nitrification reaction. It derives all of its oxygen from atmospheric $\mathrm{O}_{2}$; this results in significantly enriched values of $\delta^{18} \mathrm{O}-\mathrm{NO}_{3}$ ranging from +17 to $+25 \%[62,65]$. Thus, $\delta^{18} \mathrm{O}-\mathrm{NO}_{3}$ values may be effectively used to distinguish between ammonia in fertilizer and precipitation from that of nitrate fertilizer. For example, the study conducted by [55] revealed that the $\delta^{18} \mathrm{O}-\mathrm{NO}_{3}$ values of the borehole, hand-dug well and surface water ranged between +5.1 and $8.83 \%$ and were thus below the $\delta^{18} \mathrm{O}-\mathrm{NO}_{3}$ values of atmospheric deposition $(60$ to $70 \%$ ) and nitrate fertilizer ( +15 to $25 \%$ ). This clearly indicates that atmospheric deposition and nitrate fertilizer may not have influenced the nitrate pollution. This observation is consistent with the result obtained by [49] where the $\delta^{18} \mathrm{O}-\mathrm{NO}_{3}$ ranged between +3.84 and $+10.96 \%$. However, microbial nitrification and denitrification could have influenced the nitrate 
concentration in the study area and, thus, confirmed by the land use activities within the study area. The whole principle is that, during nitrification, the bulk of the atmospheric molecular oxygen will be utilized for the oxidation of ammonium and, therefore, the limited concentration of $\mathrm{O}_{2}$ will lead to the subsequent depletion of the $\delta^{18} \mathrm{O}$ values of the residual $\mathrm{O}_{2}$. However, several researchers reported that $\delta^{18} \mathrm{O}-\mathrm{NO}_{3}$ values were significantly depleted in the wet season but enriched in the dry season from the same source. This might have been due to evaporation induced by increased temperature, which was accompanied by the enriched $\delta^{18} \mathrm{O}$ values of $\mathrm{H}_{2} \mathrm{O}$ [61], or the nitrification processes during the dry season.

\subsection{3. $\delta^{15} \mathrm{~N}$ and $\delta^{18} \mathrm{O}$ Fingerprint of Atmospheric Deposition}

Nitrogen oxides, which are the source (s) of atmospheric nitrate, are produced during the combustion of fossil fuel from power plants and vehicle exhausts, etc. These nitrogen species undergo nitrification, denitrification and ammonia volatilization depending on the compound $\left(\mathrm{NH}_{4}^{+}\right.$or $\left.\mathrm{NO}_{3}^{-}\right)$or type of anthropogenic input in precipitation. Therefore, the $\delta^{15} \mathrm{~N}$ values of atmospheric nitrate may range from -0.6 to $+31 \%$ [53]. The fate and the associated isotopic enrichment of atmospheric nitrate can also depend on the season, meteorological conditions, distance from the ocean, and proximity to pollution sources, etc. [54]. Thus, using $\delta^{15} \mathrm{~N}$ isotope value alone could make it difficult to distinguish between atmospheric and other anthropogenic sources of nitrate. However, the $\delta^{18} \mathrm{O}-$ $\mathrm{NO}_{3}$ values can be a useful tool to distinguish between atmospheric nitrate depositions, which have higher values of 60 to $70 \%$ [54], from biologically generated nitrate in water and soil (0.8 to 5.8\% [17] or -15 to $15 \%$ [66]). The $\delta^{18} \mathrm{O}-\mathrm{NO}_{3}$ values in [53], for the majority of the samples, are above $+30 \%$. Additionally, the authors of [67] established an $\delta^{18} \mathrm{O}-\mathrm{NO}_{3}$ value of up to $34.6 \%$ in the aquifer of the Sava River. The foregoing enriched $\delta^{18} \mathrm{O}-\mathrm{NO}_{3}$ values might be associated with the atmospheric deposition of nitrate [64]. This observation is consistent with the land use activities in the study areas as there are no human activities that may have induced anthropogenic nitrate within the waterbodies. The authors of [66] also observed a high range in the $\delta^{18} \mathrm{O}$ values of rainfall $\mathrm{NO}_{3}^{-}$(65 to $70 \%$ ), which subsequently decreased to $2-5 \%$ in soil. The highly enriched $\delta^{18} \mathrm{O}$ values of atmospheric $\mathrm{NO}_{3}^{-}$may be due to the incomplete combustion of fossil fuels and/or atmospheric photochemical reactions [54]. According to [67], nitrate from atmospheric precipitation induced by photochemical reactions may involve compounds enriched with $\delta^{18} \mathrm{O}$, leading to high $\delta^{18} \mathrm{O}-\mathrm{NO}_{3}$ values. This is because, during photochemical reactions (initiated by sunlight), the concentration of the atmospheric molecular oxygen will increase, which will lead to the consequent enrichment of the $\delta^{18} \mathrm{O}$ values of the atmosphere $\left(\mathrm{O}_{2}\right)$.

\subsection{4. $\delta^{15} \mathrm{~N}$ and $\delta^{18} \mathrm{O}$ Fingerprint of Soil Nitrogen/Organic Matter}

Generally, soil $\mathrm{N}$ is often more enriched in $\delta^{15} \mathrm{~N}$ than atmospheric $\mathrm{N}$. This is because the combination of denitrification, nitrification and volatilization controls the $\delta^{15} \mathrm{~N}$ values of the total nitrogen in soil. The $\delta^{15} \mathrm{~N}$ values of soil $\mathrm{N}$ from different studies range between +3 and $8 \%$ o (Figure 3). Although mineralization and nitrification are the respective major causes of $\delta^{15} \mathrm{~N}$ enrichments in soil organic $\mathrm{N}$, other processes can also produce increases in the $\delta^{15} \mathrm{~N}$ of nitrate with depth. In summary, the use of the dual isotope of $\delta^{15} \mathrm{~N}-\mathrm{NO}_{3}^{-}$and $\delta^{18} \mathrm{O}-\mathrm{NO}_{3}^{-}$is beneficial in identifying various sources of nitrogen such as atmospheric vs. inorganic fertilizers. Unfortunately, this technique is yet to be used to differentiate between nitrogen pollution from sewage, animal manure and septic effluents, etc. Therefore, to distinguish between pollution coming from the mentioned sources, the integration of other isotopes such as $\delta^{11} \mathrm{~B}$ will be ideal.

\subsection{Integration of $\delta^{11} B$ and $\delta^{15} N$ to Identify the Factors Impacting Groundwater Pollution}

According to [68], the non-conservative nature of nitrogen causes the interference of isotope fractionation and thus impedes the precise identification of $\mathrm{NO}_{3}^{-}$sources. The preceding limitation can be tackled via the integration of $\delta^{15} \mathrm{~N}$ and boron isotope $\left(\delta^{11} \mathrm{~B}\right)[69,70]$. 
On the other hand, the increase in groundwater salinity, mainly in coastal areas, is linked to seawater intrusion or anthropogenic contamination from sewage and septic effluents. Therefore, it is vital to distinguish the sources influencing high salinity, which could also be effectively achieved using boron isotopes [71].

The two naturally occurring boron isotopes are ${ }^{10} \mathrm{~B}$ and ${ }^{11} \mathrm{~B}$. Relatively, these isotopes have large mass differences and this causes the wide natural range of $\delta^{11} \mathrm{~B}$ isotope values. The wide range of $\delta^{11} \mathrm{~B}$ isotope values enables significant contrasts between $\mathrm{B}$ sources in groundwater. Industrially, boric acid and borate minerals, which are derivatives of boron, are extensively applied to produce glass and porcelain, carpets, leather, photographic chemicals, cosmetics, fertilizers and metals [71]. Sodium perborate is also applied in domestic cleaning products as a bleaching agent. When the sodium perborate is discharged into the environment following the end use of detergents, this triggers the accumulation of boron in effluents and their consequent infiltration into waterbodies [71]. The purification of water in sewage treatment plants may remove little or no elemental B. Hence, $\delta^{11} \mathrm{~B}$ is a conservative tracer of a wastewater source [70]. Owing to the conservative nature and the wide application of B-compounds in agricultural and industrial scenarios [70], alongside its natural existence in saline water, $\delta^{11} \mathrm{~B}$ can be a useful means to determine the precise source(s) of pollutants from fertilizers, septic effluents, sewage, animal manure and sea water intrusion.

\subsection{Variations in Boron Isotope Abundance $\left(\delta^{11} B\right)$ in Natural and Anthropogenic Sources}

The use of $\delta^{11} \mathrm{~B}$ as a tracer of natural and anthropogenic impacts on water resources has mainly focused on the determination of sea water intrusion, sewage water infiltration, animal manure (hog and cattle), septic waste and inorganic fertilizers [72]. Several researchers including $[71,73]$ have evaluated the composition of ${ }^{11} \mathrm{~B}$ from both natural and anthropogenic sources but the author of [74] was the first to utilize B isotopes as co-migrating tracers of $\mathrm{NO}_{3}^{-}$.

$\delta^{11} \mathrm{~B}$ values for uncontaminated groundwater were found to be highly enriched $(30 \%)$ with a corresponding depleted boron concentration of 0.06 to $0.13 \mathrm{mg} / \mathrm{L}$ [71]. The author of [74] reported $\delta^{11} \mathrm{~B}$ values and B-concentrations of 23.8 to $25.6 \%$ and $0.02 \mathrm{mg} / \mathrm{L}$, respectively, for uncontaminated groundwater up-gradient of cultivated fields in Minnesota. The unpolluted groundwater in Bonne Fontaine spring had a $\delta^{11} \mathrm{~B}$ value of $38.5 \%$ with a corresponding B-concentration of $0.01 \mathrm{mg} / \mathrm{L}$ [68].

According to [71], seawater measurement has an average $\delta^{11} \mathrm{~B}$ value ranging from +33 to $+60 \%$ and an average B-concentration of $1.9 \mathrm{mg} / \mathrm{L}$; the highest boron concentration was estimated at $5.04 \mathrm{mg} / \mathrm{L}$ [71]. The foregoing $\delta^{11} \mathrm{~B}$ values for saline water is consistent with that obtained by [75] even though other researchers have reported $\delta^{11} \mathrm{~B}$ values of up to $70 \%$.

$\delta^{11} \mathrm{~B}$ values of untreated and treated hog manure ranged from 7.2 to $16.2 \%$ with a boron concentration of 1.43 to $8.12 \mathrm{mg} / \mathrm{L}$ [74]. However, the $\delta^{11} \mathrm{~B}$ value of the cattle (cow) manure ranged from 22.3 to $24 \%$ with a depleted boron concentration of $0.05 \mathrm{mg} / \mathrm{L}$ relative to hog manure [74]. Interestingly, groundwater down-gradient to hog manure had $\delta^{11} \mathrm{~B}$ values consistent with the hog manure whilst the $\delta^{11} \mathrm{~B}$ values of groundwater downgradient of cattle manure had enriched $\delta^{11} \mathrm{~B}$ values ranging from 32.5 to $38.6 \%$ [ [74]. The authors of [68] established that the $\delta^{11} \mathrm{~B}$ values in hog manure vary from 19.5 to $42.4 \%$ which is relatively higher than those reported by [74]. This is associated with the disparity of animal diet and physiology in US and France. In addition, the authors of [75] reported $\delta^{11} \mathrm{~B}$ values and B-concentrations of 6.2 to $8.2 \%$ and 0.15 to $0.41 \mathrm{mg} / \mathrm{L}$, respectively, for cattle (cow) manure, and these varied widely from the results of [74].

The use of boron (B) compounds in detergents causes an enrichment of $B$ in sewage effluents [68]. The boron isotopic composition of anthropogenic compounds is quite different from natural boron. This distinction can thus be used to identify different source (s) of boron contamination [71]. Studies conducted in the Dan region showed that the $\delta^{11} \mathrm{~B}$ values of treated and raw sewage effluents $\left(\delta^{11} \mathrm{~B}=+5.3\right.$ to $+12.9 \%$ o overlap with those of 
natural sodium borate $\left(\mathrm{NaBO}_{3}\right)$ minerals $(-0.9$ to $+10.2 \%$ o. This suggests that the use of $\mathrm{NaBO}_{3}$ in detergents is the main source of anthropogenic boron in sewage [71]. However, the elemental concentrations of boron in both treated and untreated sewage are merely the same and, thus, range between 0.46 and $1.06 \mathrm{mg} / \mathrm{L}$. Another study conducted elsewhere in England reported an enriched boron values in both sewage effluents (up to $4.1 \mathrm{mg} / \mathrm{L}$ ) and sewage-contaminated river water $(1.2 \mathrm{mg} / \mathrm{L})$ [71]. This suggests that the treatment of boron via clay mineral adsorption can reduce elemental boron concentration but may lead to the enrichment of $\delta^{11} \mathrm{~B}$ in sewage effluents. The $\delta^{11} \mathrm{~B}$ values in the study conducted by [68] range between 0 and $+10 \%$, which is in good agreement with data obtained for non-marine evaporites such as sodium borate. The authors of [75] used both TIMS and SF-ICP-MS instrumentation to measure $\delta^{11} \mathrm{~B}$, and the values for waste water treatment plant effluent range between -2.8 and $-0.3 \%$ with a corresponding B-concentration of $0.13 \mathrm{mg} / \mathrm{L}$. This is within the range of different borate minerals, notably sodium perborate monohydrate ( -3.9 to $0.9 \%$ ) and tetrahydrate products $(-4.8$ to $0.5 \%$ o [76]. Some of the wastewater samples analyzed by [75] also have $\delta^{11} \mathrm{~B}$ values of $6 \%$, which is within the range reported by the authors of [71]. Relatively, some of the reported values of boron isotopes $\left(\delta^{11} \mathrm{~B}\right)$ (approximately +3 to $+10 \%$ ) in leachate at MSW landfills overlap with those of sewage and wastewater [19].

The variable increase in $\delta^{11} \mathrm{~B}$ isotope composition with a corresponding decrease in boron concentration in the groundwater of sewage and animal manure is linked with the adsorption of $\mathrm{B}$ onto clay minerals and organic matter. The dominant boron species in aquatic systems are boric acid $\mathrm{B}(\mathrm{OH})_{3}$ and borates $\mathrm{B}(\mathrm{OH})_{4}^{-}$which are in isotopic equilibrium, as shown in Equation (7) [71,74,75].

$$
{ }^{11} \mathrm{~B}(\mathrm{OH})_{3}+{ }^{10} \mathrm{~B}(\mathrm{OH})_{4}^{-} \leftrightharpoons{ }^{10} \mathrm{~B}(\mathrm{OH})_{3}+{ }^{11} \mathrm{~B}(\mathrm{OH})_{4}^{-}
$$

During the interaction of water with sediments in the aquifer, boron is absorbed by clay minerals or organic matter. Owing to its larger isotopic reduced partition function ratios, the heavy boron isotope preferentially partitions into boric acid, forming ${ }^{11} \mathrm{~B}(\mathrm{OH})_{3}$, whereas the lighter isotope partitions into the tetrahedrally coordinated B species, forming ${ }^{10} \mathrm{~B}(\mathrm{OH})_{4}^{-}[71,74]$. The $\mathrm{B}$ adsorption in clays and other ion-exchange media preferentially removes ${ }^{10} \mathrm{~B}(\mathrm{OH})_{4}^{-}$from the solution, leaving the residual $\mathrm{B}$ enriched in ${ }^{11} \mathrm{~B}$. Similar adsorption phenomena occur for organic materials, where ${ }^{10} \mathrm{~B}(\mathrm{OH})_{4}^{-}$is preferentially removed from the solution, causing an enrichment in ${ }^{11} \mathrm{~B}$ [74]. The adsorption magnitude of these boron species onto clay minerals depends on the concentration of boron in the solution, as well as the $\mathrm{pH}$, salinity, clay content and mineralogy, organic carbon and cation exchange capacity.

The author of [74] evaluated the $\delta^{11} \mathrm{~B}$ isotope and $\mathrm{B}$ concentration values of different inorganic fertilizers and the results are as follows: $\mathrm{NH}_{4} \mathrm{NO}_{3}\left(\delta^{11} \mathrm{~B} \sim 0.7 \%\right.$, $\left.\mathrm{B} \sim 2.4 \mathrm{mg} / \mathrm{L}\right)$, Urea $\left(\delta^{11} \mathrm{~B} \sim 0.4 \%\right.$ o $\left.\mathrm{B} \sim 0.46 \mathrm{mg} / \mathrm{L}\right)$ and $\mathrm{PO}_{4}^{-}\left(\delta^{11} \mathrm{~B} \sim 14.8 \%\right.$, $\left.\mathrm{B} \sim 13.3 \mathrm{mg} / \mathrm{L}\right)$. The $\delta^{11} \mathrm{~B}$ values $(20.6 \%$ o $)$ and B-composition $(0.07 \mathrm{mg} / \mathrm{L})$ of urea in the research of [75] are significantly different from those obtained in [74]. The results given in [75] also depict variable $\delta^{11} \mathrm{~B}$ compositions and B concentrations ( 0.2 to $7.2 \%$ and 2.7 to $13.9 \mathrm{mg} / \mathrm{L}$, respectively) for NPK fertilizers based on differences in the proportions of N, P and K. Hence, the foregoing ranges of boron concentration and $\delta^{11} \mathrm{~B}$ isotopes from different studies are compiled and plotted against $\delta^{15} \mathrm{~N}-\mathrm{NO}_{3}$ values obtained by other researchers to easily aid a precise distinction of animal manures from sewage and dumpsite leachates (Figure 4). It can be observed that the ${ }^{11} \mathrm{~B}$ isotope values of pig manure overlap with cattle manure, but the elemental boron concentrations of pig manure are significantly higher than those of the cattle manure (Figure 4). Hence, elemental boron concentration could be reliably used to differentiate between cattle and pig manures. Elemental $\mathrm{B}$ and $\delta^{11} \mathrm{~B}$ isotopes cannot be used to differentiate between landfill leachate and domestic sewage; thus, the use of tritium isotope will be key when considering landfills as a source of pollution. 


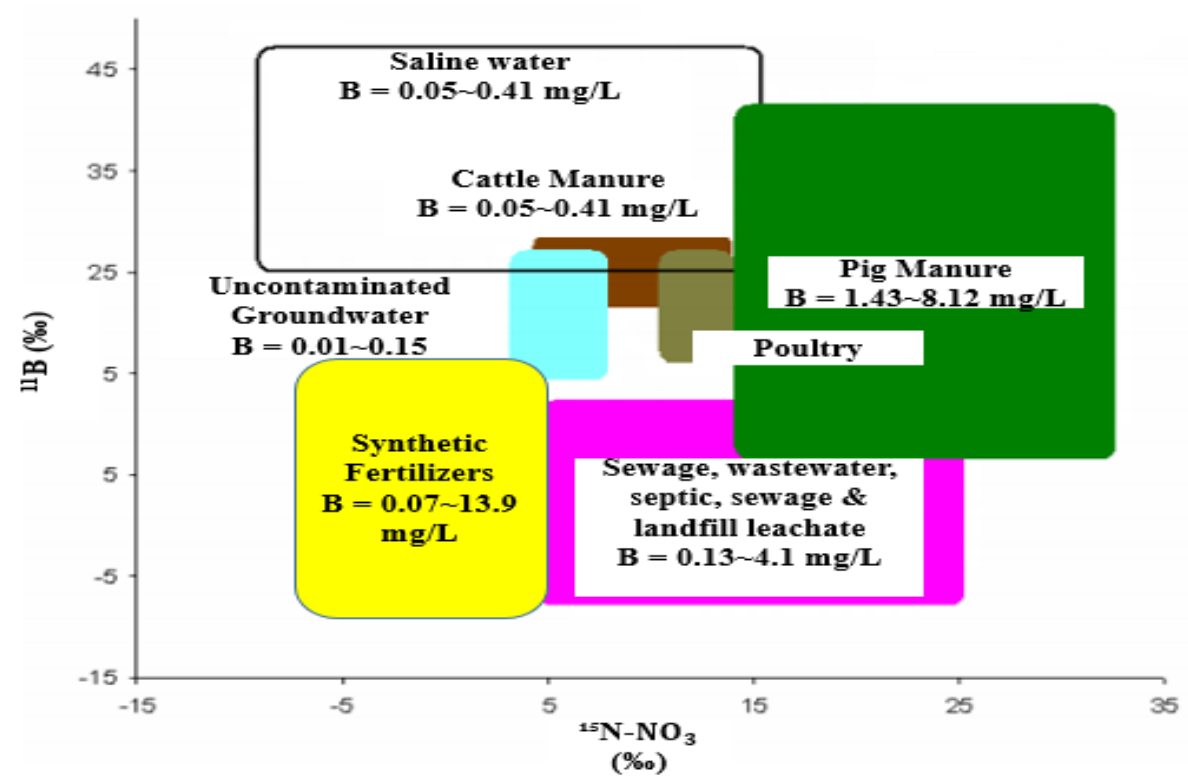

Figure 4. Typical $\delta^{11} \mathrm{~B}$ versus $\delta^{15} \mathrm{~N}-\mathrm{NO}_{3}$ values derived from various nitrates from pollution sources.

\subsection{Applications of $\delta^{11} B$ as a Pollution Tracer}

Recent studies (2010 to 2020) in Spain, Portugal and Italy showed that the combined use of $\delta^{15} \mathrm{~N}-\mathrm{NO}_{3}^{-}, \delta^{18} \mathrm{O}-\mathrm{NO}_{3}^{-}$and $\delta^{11} \mathrm{~B}$ is ideal to identify the source(s) of contamination from organic and inorganic fertilizers, animal manures, septic and domestic waste, and seawater intrusion. The authors of [77] carried out studies at the Baix Ter Aquifer in Spain to identify the sources of contamination and the processes affecting the nitrate concentration of a watershed. The $\delta^{15} \mathrm{~N}^{-\mathrm{NO}_{3}^{-}}$and $\delta^{18} \mathrm{O}-\mathrm{NO}_{3}^{-}$values ranged from +5.0 to $+32 \%$ and +8.9 to $+18.1 \%$, respectively. The results indicated that sewage, animal manure and dumpsite leachates could be the induced sources of nitrate. A similar observation was put forward by the authors of [78] in Portugal, where some of the samples had higher $\delta^{15} \mathrm{~N}-\mathrm{NO}_{3}^{-}$and $\delta^{18} \mathrm{O}-\mathrm{NO}_{3}^{-}$values, suggesting possible animal manure and sewage infiltration. The $\delta^{11} \mathrm{~B}$ isotope was employed in both studies to ascertain the precise source(s) of pollution [68,74] In the study of [77], two samples had $\delta^{11} \mathrm{~B}$ concentrations that ranged from +1.4 to $+9.0 \%$ which indicated sewage contamination (Figure 4) $[68,71,74]$. This was attributed to the downstream location of the foregoing wells at the La Bishal treatment plant, which may have induced Borate ions. Ten samples had $\delta^{11} \mathrm{~B}$ values of 23.5 to $34.5 \%$, which fell within the range of pig manure. This is in agreement with the studies of [78] whose $\delta^{11} \mathrm{~B}$ values ranged between +28.5 and $+44 \%$ and fell within the range of pig manure (Figure 4). The author of [47] used $\delta^{15} \mathrm{~N}-\mathrm{NO}_{3}^{-}$and $\delta^{18} \mathrm{O}-\mathrm{NO}_{3}^{-}$to identify synthetic and organic sources of pollution in the Turin-Cuneo plain, Italy. Moreover, $\delta^{11} \mathrm{~B}$ isotopes were used to further delineate the main anthropogenic sources of pollution. The $\delta^{11} \mathrm{~B}$ result ranged from 8.37 to $18.05 \%$, which predicted sewage $(+8.37 \%$ ) and an overlap between cattle and hog manure (18 to $42 \%$ ) as the principal sources of pollution. Considering the concentration of boron $(0.06$ to $0.09 \mathrm{mg} / \mathrm{L})$, the possible source could be the cattle manure as opposed to the hog manure postulated in the literature. This is because most studies [68,71,74] reported boron concentrations of 1.43 to $8.12 \mathrm{mg} / \mathrm{L}$ for pig manure and 0.05 to $0.41 \mathrm{mg} / \mathrm{L}$ for cow manure; thus, cow manure may be the precise source. This is consistent with the land use activities within the study area, such as sewage treatment and agricultural activities (cattle rearing).

\section{Quick Guide to Pollution Source Identification Using Isotope Analysis}

Isotopic applications to investigate groundwater pollution sources represent one of the most integral aspects of water quality management. However, the understanding and interpretation of this technique is a challenge for many stakeholders involved in water quality management. Therefore, Table 5 proffers a quick guideline for scientists and policy makers to implement a multi-isotope approach for pollution source identification. 
Table 5. Quick guide to pollution source identification.

\begin{tabular}{|c|c|c|c|c|c|}
\hline Stages & Parameters & Methodology & Characteristics Ranges & & References \\
\hline \multirow{4}{*}{$\begin{array}{l}\text { Step 1: The first step to identify } \\
\text { the source (s) of water pollution } \\
\text { near a landfill site is to determine } \\
\text { the percolation of leachate using } \\
\text { a stable isotope approach. } \\
\text { However, isotopic samples } \\
\text { should be collected alongside } \\
\text { ongoing chemical analysis to } \\
\text { reduce costs. }\end{array}$} & \multirow[t]{4}{*}{$\begin{array}{l}\delta^{18} \mathrm{O} \\
\delta^{2} \mathrm{H} \\
\delta 13 \mathrm{C}\end{array}$} & \multirow{4}{*}{$\begin{array}{l}\mathrm{CO}_{2}-\mathrm{H}_{2} \mathrm{O} \text { Equilibration. The method involves } \\
\text { equilibrating } 5 \mathrm{~mL} \text { of the samples with } \mathrm{CO}_{2} \text { gas for } 24 \\
\text { h. at } 25 \pm 0.1^{\circ} \mathrm{C} \text {. Cr at } 850{ }^{\circ} \mathrm{C} \text { is utilized for the } \\
\text { reduction of } \mathrm{H}_{2} \mathrm{O}_{(1)} \text { to produce } \mathrm{H}_{2}(\mathrm{~g}) \text {. Both the } \\
\delta^{18} \mathrm{O} \text { and } \delta^{2} \mathrm{H} \text { contents are determined using a Liquid } \\
\text { Water Isotope Analyzer. Evacuated glass septum vials, } \\
\text { pre-filled with phosphoric acid ( } 85 \% \text { ) and a magnetic } \\
\text { stirrer are used to collect water samples for } \delta^{13} \mathrm{C} \\
\text { analyses. The sealed vacuum sample is acidified, and } \\
\text { cryogenic traps are used to purify the produced } \mathrm{CO}_{2} \text {. } \\
\text { Isotope-ratio mass spectrometry (IRMS) is used to } \\
\text { measure the isotopic ratio of } \delta 13 \mathrm{CDIC} \\
\text { Disadvantages of IRMS technique } \\
\text { Sampling of soil using IRMS is time-consuming as } \\
\text { IRMS is not operated in the field [79]. The IRMS } \\
\text { technique requires pretreatment (liquid conversion to } \\
\text { gaseous samples), and is not applicable for field } \\
\text { measurement; this limits the number of samples that } \\
\text { can be analyzed in a given period [80]. } \\
\text { Alternative method to measure } \delta^{18} \mathrm{O}, \delta^{2} \mathrm{H} \& \delta^{13} \mathrm{C} \\
\text { Cavity Ring-down Spectroscopy (CRDS) (laser } \\
\text { absorption technique) is the current alternative } \\
\text { measurement to Isotope-ratio mass spectrometry. The } \\
\text { principle of CRDS involves the measurement of the } \\
\text { rate of decay (ring-down time) of a laser beam's } \\
\text { intensity [80]. Comparable to IRMS, its potability, } \\
\text { simple operation, relatively cheap labor and } \\
\text { equipment cost }(<\$ 50 \mathrm{~K} \text { ) and applicability at remote } \\
\text { sites make CRDS technology useful for developing } \\
\text { countries [79]. CRDS has a comparable precision to } \\
\text { IRMS [81]. CRDS can be used for elemental and } \\
\text { isotopic measurements such as } \mathrm{C}, \mathrm{O}, \mathrm{N} \text {, and } \mathrm{H} \text { in } \\
\text { organic or inorganic samples [ } 82,83 \text { ]. The presence of } \\
\text { dissolved organic molecules has the disadvantage of } \\
\text { degrading the analytical performance of } \mathrm{CRDS} \text { due to } \\
\text { spectral interferences [ } 84 \text { ]. }\end{array}$} & $\begin{array}{l}\text { Leachate water } \\
\delta^{18} \mathrm{O}-4.5 \text { to } 3.7 \% \\
\delta^{2} \mathrm{H}-22 \text { to }+60 \% \\
\end{array}$ & $\begin{array}{l}\text { Uncontaminated water } \\
\delta^{18} \mathrm{O}-4.1 \text { to }-4.4 \% \text { o } \\
\delta^{2} \mathrm{H}-23 \text { to }-25.5 \% \text { o }\end{array}$ & \multirow[t]{4}{*}{ [25] } \\
\hline & & & \multicolumn{2}{|c|}{$\begin{array}{l}\text { ( } \delta^{2} \mathrm{H} \text { is enriched due to methanogenesis) } \\
\text { Note: Unlike } \delta^{2} \mathrm{H}, \delta^{18} \mathrm{O} \text { is unaffected by methanogenesis }\end{array}$} & \\
\hline & & & $\begin{array}{l}\text { Calcite dissolution } \\
\delta 13 \mathrm{C}-14 \text { to }+1.1 \% \text { o }\end{array}$ & $\begin{array}{l}\text { Leachate } \\
\delta 13 C+16 \text { to }+21.2 \%\end{array}$ & \\
\hline & & & $\begin{array}{l}\text { Leachate polluted Groundwater } \\
\delta 13 \mathrm{C}+5 \text { to }+38 \% \text { o }\end{array}$ & & \\
\hline
\end{tabular}


Table 5. Cont.

\begin{tabular}{|c|c|c|c|c|c|}
\hline Stages & Parameters & Methodology & Characteristics Ranges & & References \\
\hline \multirow{3}{*}{$\begin{array}{l}\text { Step 2: The } \mathrm{NO}_{3}^{-} \text {data are } \\
\text { vital to define the status of } \\
\text { groundwater and surface } \\
\text { water. If the } \mathrm{NO}_{3}^{-} \\
\text {concentration is higher than } \\
\text { the } \mathrm{WHO} \text { limit }(50 \mathrm{mg} / \mathrm{L}) \text {, it } \\
\text { is necessary to identify its } \\
\text { source(s) for further } \\
\text { prevention measures. }\end{array}$} & \multirow[t]{3}{*}{$\delta^{15} \mathrm{~N}$ and $\delta^{18} \mathrm{O}$} & \multirow{3}{*}{$\begin{array}{l}\text { Bacteria denitrification } \\
\mathrm{NO}_{3}^{-} \rightarrow \mathrm{N}_{2} \mathrm{O} \\
\text { extraction: online (auto } \\
\text { sampler); measurement: } \\
\text { IRMS }\end{array}$} & $\begin{array}{l}\text { Precipitation } \\
\delta^{15} \mathrm{~N}-0.6 \text { to } 31 \% \\
\delta^{18}+30 \text { to } 70 \%\end{array}$ & $\begin{array}{l}\text { Soil Nitrogen } \\
\delta^{15} \mathrm{~N}+3 \text { to }+8 \% \text { o } \\
\delta^{18} \mathrm{O}-8 \text { to }+12 \%\end{array}$ & \multirow[t]{3}{*}{$53,54,61,62,65,85$} \\
\hline & & & $\begin{array}{l}\mathrm{NH}_{4}^{+} \text {in Fertilizer Synthetic } \\
\delta^{15} \mathrm{~N}-8 \text { to }+7 \% \\
\delta^{18} \mathrm{O}-8 \text { to }+12 \%\end{array}$ & $\begin{array}{l}\mathrm{NO}_{3}^{-} \text {Fertilizer } \\
\delta^{15} \mathrm{~N}-5 \text { to }+8 \% \\
\delta^{18} \mathrm{O}+17 \text { to }+25 \%\end{array}$ & \\
\hline & & & \multicolumn{2}{|c|}{ 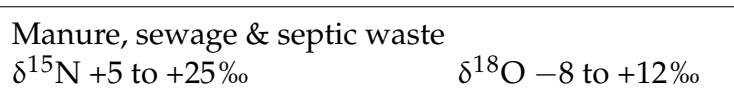 } & \\
\hline \multirow{4}{*}{$\begin{array}{l}\text { Step 3: Following potential } \\
\text { scenarios where multiple } \\
\text { nitrate sources could be } \\
\text { involved, } \delta^{11} \mathrm{~B} \text { should be } \\
\text { used to further identify the } \\
\text { specific nitrate source (s). }\end{array}$} & \multirow[t]{4}{*}{$\delta^{11} B$} & \multirow{4}{*}{$\begin{array}{l}\text { The boron isotope } \\
\text { composition can be } \\
\text { determined by using Thermal } \\
\text { Ionization } \\
\text { Mass-Spectrometry (TIMS). } \\
\text { The amberlite IRA-743 boron } \\
\text { selective resin method can be } \\
\text { employed to isolate the } \\
\text { boron. }\end{array}$} & \multicolumn{2}{|c|}{$\begin{array}{l}\text { Uncontaminated Groundwater } \\
\delta^{11} \mathrm{~B}+23.8 \text { to }+38.5 \% \\
\mathrm{~B} 0.015 \text { to } 0.15 \mathrm{mg} / \mathrm{L}\end{array}$} & \multirow[t]{4}{*}{ [86] } \\
\hline & & & $\begin{array}{l}\text { Seawater } \\
\delta^{11} \mathrm{~B}+33 \text { to }+70 \% \text { o } \\
\text { B } 0.07 \text { to } 13.9 \mathrm{mg} / \mathrm{L}\end{array}$ & $\begin{array}{l}\text { Synthetic fertilizer } \\
\delta^{11} \mathrm{~B}-6 \text { to }+5 \% \text { o } \\
\text { B } 0.05 \text { to } 0.41 \mathrm{mg} / \mathrm{L}\end{array}$ & \\
\hline & & & $\begin{array}{l}\text { Hog Manure } \\
\delta^{11} \mathrm{~B}+7.2 \text { to }+42.5 \% \text { o } \\
\text { B } 1.43 \text { to } 8.12 \mathrm{mg} / \mathrm{L}\end{array}$ & $\begin{array}{l}\text { Cattle Manure } \\
\delta^{11} \mathrm{~B}+22.3 \text { to }+24 \% \text { o } \\
\text { B } 0.05 \text { to } 0.41 \mathrm{mg} / \mathrm{L}\end{array}$ & \\
\hline & & & \multicolumn{2}{|c|}{$\begin{array}{l}\text { Sewage, landfill and septic leachates } \\
\delta^{11} \mathrm{~B}+5 \text { to }+25 \% \text { B } 0.13 \text { to } 4.1 \mathrm{mg} / \mathrm{L}\end{array}$} & \\
\hline \multirow{3}{*}{$\begin{array}{l}\text { Step 4: Since all the above } \\
\text { techniques cannot be used to } \\
\text { differentiate between septic } \\
\text { and landfill leachates, } 3 \mathrm{H} \\
\text { isotope could be used to } \\
\text { isolate dumpsite leachate. }\end{array}$} & \multirow[t]{3}{*}{ Tritium } & \multirow{3}{*}{$\begin{array}{l}\text { Electrolytic enrichment } \\
\text { method. The tritium } \\
\text { concentration is then } \\
\text { measured via b-particle } \\
\text { counting emission using a } \\
\text { liquid scintillation counter. }\end{array}$} & $\begin{array}{l}\text { Leachate } \\
\text { ( } 50.9 \text { to } 159,316 \mathrm{TU})\end{array}$ & & \multirow[t]{3}{*}[16,21,22,30]{} \\
\hline & & & \multicolumn{2}{|l|}{$\begin{array}{l}\text { Groundwater polluted by leachate } \\
\text { (2.3 to } 76.6 \mathrm{TU})\end{array}$} & \\
\hline & & & $\begin{array}{l}\text { Unpolluted water } \\
\text { (0.04 to } 10 \mathrm{TU})\end{array}$ & $\begin{array}{l}\text { Precipitation } \\
(<10 \mathrm{TU})\end{array}$ & \\
\hline
\end{tabular}




\section{Conclusions}

Earlier groundwater studies in relation to dumpsites were mainly focused on using hydrochemical data, which can provide information about the concentration of pollutants in water bodies. Geophysical methods can be used to determine the extent of pollution and possible leachate migration but cannot be applied to determine the specific sources of the leachates or pollution.

Because $\delta^{2} \mathrm{H}$ and $\delta^{13} \mathrm{C}$ values are enriched whilst $\delta^{18} \mathrm{O}$ remains unaffected during methanogenesis, these isotopes could be used to confirm leachate migration to water bodies. The shortcoming of this method is that it cannot depict the specific sources, dumpsites leachate versus sewage or animal manures since all of these sources can significantly induce methane gas.

The high tritium (2000 TU) in the atmosphere between 1952 and 1963, which was caused by nuclear bomb testing, has decayed to less than $10 \mathrm{TU}$. Therefore, the tritium in modern precipitation and groundwater mainly originates from atmospheric deposition (cosmic radiation) and landfill leachate, respectively. The combination of tritium and stable isotopes $\left(\delta^{1} 8 \mathrm{O}\right.$ and $\left.\delta^{2} \mathrm{H}\right)$ seems to be potentially invaluable in terms of determining the sources of leachates. The $\delta^{15} \mathrm{~N}$ technique has been successfully used to distinguish between synthetic and organic nitrogen sources but its application is limited to differentiating between atmospheric versus inorganic nitrogen sources. The use of a dual isotope of $\delta^{15} \mathrm{~N}-\mathrm{NO}_{3}^{-}$and $\delta^{18} \mathrm{O}-\mathrm{NO}_{3}^{-}$is beneficial in identifying various sources of nitrogen such as atmospheric and inorganic fertilizers, but it is yet to be used to differentiate between nitrogen pollution caused by denitrification, i.e., sewage versus animal manure. Thus, the coupling of the ${ }^{11} \mathrm{~B}$ isotope with $\delta^{15} \mathrm{~N}-\mathrm{NO}_{3}^{-}$and $\delta^{18} \mathrm{O}-\mathrm{NO}_{3}^{-}$and other hydrochemical parameters has proven to be effective in distinguishing between nitrate fertilizer, animal manure, seawater contamination and sewage because the ${ }^{11} \mathrm{~B}$ isotope is not influenced by physical, chemical and microbiological processes.

To date, there is no existing study that combines all of the discussed isotope approaches to identify groundwater pollution sources. Therefore, in areas affected by agricultural activities, landfill leachates, domestic or sewage effluent, and seawater intrusion, it is incumbent to couple hydrochemical $\left(\mathrm{Cl}^{-}, \mathrm{NO}_{3}^{-}, \mathrm{B}, \mathrm{DO}\right)$ and isotope techniques $\left(\delta^{18} \mathrm{O}, \delta^{2} \mathrm{H}\right.$, $\delta^{13} \mathrm{C}, \delta^{15} \mathrm{~N}-\mathrm{NO}_{3}^{-}, \delta^{18} \mathrm{O}-\mathrm{NO}_{3}^{-}, \delta^{11} \mathrm{~B}$ and $\left.{ }^{3} \mathrm{H}\right)$ to effectively identify the pollution sources of groundwater in developing countries. The research outlined here will provide guidelines for further studies that may aim to critically distinguish between pollution sources from dumpsites, sewage runoff, septic leachates and seawater intrusion.

Author Contributions: Conceptualization, A.A.S.; formal analysis, A.A.S., R.A.D.F.-w. and C.L.; writing—original draft preparation, A.A.S.; writing—review and editing, A.A.S., R.A.D.F.-w., N.S.A.D., C.L. and I.K.; supervision, N.S.A.D., R.A.D.F.-w. and C.L. All authors have read and agreed to the published version of the manuscript.

Funding: This review was funded by the Regional Centre for Energy and Environmental Sustainability (RCEES), UENR.

Institutional Review Board Statement: Not applicable.

Informed Consent Statement: Not applicable.

Data Availability Statement: All data used were already referenced.

Acknowledgments: The support of the Regional Centre for Energy and Environmental Sustainability (RCEES), UENR, is acknowledged.

Conflicts of Interest: The authors declare no conflict of interest.

\section{References}

1. Aboyeji, O.S.; Eigbokhan, S.F. Evaluations of groundwater contamination by leachates around Olusosun open dumpsite in Lagos metropolis, southwest Nigeria. Environ. Manag. 2016, 183, 333-341. [CrossRef]

2. Ahring, B.K.; Biswas, R.; Ahamed, A.; Teller, P.J.; Uellendahl, H. Making lignin accessible for anaerobic digestion by wet-explosion pretreatment. Bioresour. Tech. 2015, 175, 182-188. [CrossRef] 
3. Kumar, S.; Dhar, H.; Nair, V.V.; Rena; Govani, J.; Arya, S.; Bhattacharya, J.K.; Vaidya, A.N.; Akolkar, A.B. Environmental quality monitoring and impact assessment of solid waste dumpsites in high altitude sub-tropical regions. Environ. Manag. 2019, 252, 109681. [CrossRef]

4. Liu, S.; Wu, F.; Feng, W.; Guo, W.; Song, F.; Wang, H.; Wang, Y.; He, Z.; Giesy, J.P.; Zhu, P.; et al. Using dual isotopes and a Bayesian isotope mixing model to evaluate sources of nitrate of Tai Lake, China. Environ. Sci. Poll. Res. 2018, 25, 32631-32639. [CrossRef] [PubMed]

5. $\mathrm{Xu}, \mathrm{S}$.; Kang, P.; Sun, Y.A. Stable isotope approach and its application for identifying nitrate source and transformation process in water. Environ. Sci. Poll. 2016, 23, 1133-1148. [CrossRef]

6. Loague, K.; Corwin, D.L. Point and NonPoint Source Pollution. Encyclo. of Hydro. Sci. 2006, 4, 1-13. [CrossRef]

7. Nisi, B.; Raco, B.; Dotsika, E. Groundwater Contamination Studies by Environmental Isotopes: A review. Hdb. Environ. Chem. Pollut. Wastes 2014. [CrossRef]

8. Gugulothu, S.; Dhakate, R.; Sreedhar, K. Geophysical and hydrochemical studies for sustainable development of groundwater resources in northwestern part of Telangana State, India. J. Earth Syst. Sci. 2020, 129, 202. [CrossRef]

9. Ameloko, A.A.; Ayolabi, E.A. Geophysical assessment for vertical leachate migration profile and physicochemical study of groundwater around the Olusosun dumpsite Lagos, south-west Nigeria. Appl. Water Sci. 2018, 8, 142. [CrossRef]

10. Alfaifi, H.; Kahal, A.; Albassam, A. Integrated geophysical and hydrochemical investigations for seawater intrusion: A case study in southwestern Saudi Arabia. Arab. J. Geosci. 2019, 12, 372. [CrossRef]

11. Karlık, G.; Kaya, M.A. Investigation of groundwater contamination using electric and electromagnetic methods at an open waste-disposal site: A case study from Isparta, Turkey. Environ. Geol. 2001, 40, 725-731. [CrossRef]

12. Jia, H.; Howard, K.; Qian, H. Use of multiple isotopic and chemical tracers to identify sources of nitrate in shallow groundwaters along the northern slope of the Qinling. Appl. Geochem. 2020, 113, 104512. [CrossRef]

13. Oteng, F.; Alo, C.; Yidana, S.M. Evaluation of groundwater recharge estimates in a partially metamorphosed sedimentary basin in a tropical environment: Application of natural tracers. Sci. World J. 2014, 2014, 8. [CrossRef]

14. Yidana, S.M.; Alo, C.; Addai, M.O.; Fynn, O.F.; Essel, S.K. Numerical analysis of groundwater flow and potential in parts of a crystalline aquifer system in Northern Ghana. Environ. Sci. Tech. 2015, 12, 3805-3818. [CrossRef]

15. Adomako, D.; Maloszewski, P.; Stumpp, C.; Osae, S.; Akiti, T. Estimating groundwater recharge from water isotope ( $\delta 2 \mathrm{H}, \delta 18 \mathrm{O})$ depth profiles in the Densu River basin, Ghana. Hydrol. Sci. J. 2010, 55, 1405-1416. [CrossRef]

16. Pujiindiyati, E.R.; Sidauruk, P. Study of leachate contamination in bantar gebang landfill to its shallow groundwater using natural isotope tracers of 18O, $2 \mathrm{H}$ and 3H. At. Indones. 2015, 41,31-39. [CrossRef]

17. Chen, F.; Zhou, X.; Lao, Q.; Wang, S.; Jin, G.; Chen, C.; Zhu, Q. Dual isotopic evidence for nitrate sources and active biological transformation in the Northern South China Sea in summer. PLoS ONE 2019, 14, 1-16. [CrossRef]

18. Zimmermann, J.L.; Halloran, J.S.; Hunkeler, D. Tracking chlorinated contaminants in the subsurface using compound-specific chlorine isotope analysis: A review of principles, current challenges and applications. Chemosphere 2020, 244, 125476. [CrossRef]

19. Nigro, A.; Sappa, G.; Barbieri, M. Application of boron and tritium isotopes for tracing landfill contamination in groundwater. Geochem. Explor. 2017, 172, 101-108. [CrossRef]

20. Edmunds, W.M. Contribution of isotopic and nuclear tracers to study of groundwaters. Oxf. Cent. Wat. Res. 2005, 171-172. [CrossRef]

21. Castañeda, S.S.; Sucgang, R.J.; Almoneda, R.V.; Mendoza, N.D.S.; David, C.P.C. Environmental isotopes and major ions for tracing leachate contamination from a municipal landfill in Metro Manila, Philippines. Environ. Radioact. 2012, 110, 30-37. [CrossRef] [PubMed]

22. Ramaroson, V.; Rakotomalala, C.U.; Rajaobelison, J.; Fareze, L.P.; Razafitsalama, F.A.; Rasolofonirina, M. Tritium as tracer of groundwater pollution extension: Case study of Andralanitra landfill site, Antananarivo-Madagascar. Appl. Wat. Sci. 2018, 8, 1-11. [CrossRef]

23. Wimmer, B.; Hrad, M.; Huber-Humer, M.; Watzinger, A.; Wyhlidal, S.; Reichenauer, T.G. Stable isotope signatures for characterising the biological stability of landfilled municipal solid waste. Waste Manag. 2013, 33, 2083-2090. [CrossRef] [PubMed]

24. Mukherjee, S.; Mukhopadhyay, S.; Hashim, M.A.; Sen Gupta, B. Contemporary environmental issues of landfill leachate: Assessment and remedies. Crit. Rev. Environ. Sci. Tech. 2015, 45, 472-590. [CrossRef]

25. Lee, K.S.; Ko, K.S.; Kim, E.Y. Application of stable isotopes and dissolved ions for monitoring landfill leachate contamination. Environ. Geochem. Health 2020, 42, 1387-1399. [CrossRef] [PubMed]

26. Andrei, F.; Barbieri, M.; Sappa, G. Application of $2 \mathrm{H}$ and18O isotopes for tracing municipal solid waste landfill contamination of groundwater: Two Italian case histories. Water 2021, 13, 1065. [CrossRef]

27. Fenchel, T.; King, G.M.; Blackburn, T.H. Bacterial Metabolism. Bact. Biogeochem. 2012, 1-34. [CrossRef]

28. Meckenstock, R.U.; Morasch, B.; Griebler, C.; Richnow, H.H. Stable isotope fractionation analysis as a tool to monitor biodegradation in contaminated acquifers. J. Contam. Hydrol. 2004, 75, 215-255. [CrossRef]

29. North, J.C.; Frew, R.D.; Van Hale, R. Can stable isotopes be used to monitor landfill leachate impact on surface waters? J. Geochem. Explor. 2006, 88, 49-53. [CrossRef]

30. Hughes, C.E.; Cendón, D.I.; Harrison, J.J.; Hankin, S.I.; Johansen, M.P.; Payne, T.E.; Vine, M.; Collins, R.N.; Hoffmann, E.L.; Loosz, T. Movement of a tritium plume in shallow groundwater at a legacy low-level radioactive waste disposal site in eastern Australia. J. Environ. Radioact. 2011, 102, 943-952. [CrossRef] [PubMed] 
31. Kerfoot, H.B.; Baker, J.A.; Burt, D.M. The use of isotopes to identify landfill gas effects on groundwater. J. Environ. Monit. 2003, 5, 896-901. [CrossRef]

32. Tazioli, A. Landfill investigation using tritium and isotopes as pollution tracers. AQUA Mundi 2011, 18, 83-92. [CrossRef]

33. Robinson, H.D.; Gronow, J.R. Tritium levels in leachates and condensates from domestic wastes in landfill sites. Water Environ. J. 1996, 100, 391-398. [CrossRef]

34. Bandeira, J.V.; Mingote, R.M.; Baptista, M.B.; Oliveira, D.M.; Lima, F.P. The use of tritium content as an indicator of the groundwater contamination by sanitary landfills leachates in the region of Belo Horizonte City, Brazil. Water Sci. Tech. 2008, 57, 1915-1920. [CrossRef] [PubMed]

35. MacFarlane, D.S.; Cherry, J.A.; Gillham, R.W.; Sudicky, E.A. Migration of contaminants in groundwater at a landfill: A case study. 1. Groundwater flow and plume delineation. Hydro 1983, 63, 1-29. [CrossRef]

36. Mutch, R.D.; Mahony, J.D. A study of tritium in municipal solid waste leachate and gas. Fusion Sci. Tech. 2008, 54, 305-310. [CrossRef]

37. Raco, B.; Dotsika, E.; Battaglini, R.; Bulleri, E.; Doveri, M.; Papakostantinou, K. A quick and reliable method to detect and quantify contamination from MSW landfills: A case study. Water Air Soil Poll. 2013, 224, 1-18. [CrossRef]

38. Porowska, D. Determination of the origin of dissolved inorganic carbon in groundwater around a reclaimed landfill in Otwock using stable carbon isotopes. Waste Manag. 2015, 39, 216-225. [CrossRef]

39. Cole, J.J.; Prairie, Y.T. Dissolved $\mathrm{CO}_{2}$ in Freshwater Systems. In Reference Module in Earth Systems and Environmental Sciences; Elsevier Inc.: Amsterdam, The Netherlands, 2014. [CrossRef]

40. Preziosi, E.; Frollini, E.; Zoppini, A.; Ghergo, S.; Melita, M.; Parrone, D.; Rossi, D.; Amalfitano, S. Disentangling natural and anthropogenic impacts on groundwater by hydrogeochemical, isotopic and microbiological data: Hints from a municipal solid waste landfill. Waste Manag. 2019, 84, 245-255. [CrossRef]

41. Kohl, D.H.; Shearer, G.B.; Commoner, B. Fertilizer nitrogen: Contribution to nitrate in surface water in a corn belt watershed. Science 1971, 24, 1331-1334. [CrossRef]

42. Charles, B.; Iii, A.C.; Groat, C.G. Use of Stable Isotopes of Carbon, Nitrogen, and Sulfur to Identify Sources of Nitrogen in Surface Waters in the Lower Susquehanna River Basin, Pennsylvania; US Government Printing Office: Washington, DC, USA, 2005.

43. Curt, M.D.; Aguado, P.; Sánchez, G.; Bigeriego, M.; Fernández, J. Nitrogen isotope ratios of synthetic and organic sources of nitrate water contamination in Spain. Water Air Soil Pollut. 2004, 151, 135-142. [CrossRef]

44. Li, X.; Masuda, H.; Koba, K.; Zeng, H. Nitrogen isotope study on nitrate-contaminated groundwater in the Sichuan Basin, China. Water Air Soil Pollut. 2007, 178, 145-156. [CrossRef]

45. Ren, Y.; Xu, Z.; Zhang, X.; Wang, X.; Sun, X.; Ballantine, D.J.; Wang, S. Nitrogen pollution and source identi fi cation of urban ecosystem surface water in Beijing. Front. Environ. Sci. Eng. 2014, 8, 106-116. [CrossRef]

46. Minet, E.; Coxon, C.E.; Goodhue, R.; Richards, K.G.; Kalin, R.M.; Meier-Augenstein, W. Evaluating the utility of $15 \mathrm{~N}$ and $18 \mathrm{O}$ isotope abundance analyses to identify nitrate sources: A soil zone study. Water Res. 2012, 46, 3723-3736. [CrossRef] [PubMed]

47. Luca, D.A. Evaluation of sources and fate of nitrates in the western Po plain groundwater (Italy) using nitrogen and boron isotopes. Environ. Sci. Pollut. Res. 2017, 26, 2089-2104.

48. Benjamin, S.M.; Nyilitya, P.B. Kisumu City and Kano Plains, Kenya. Water 2020, 12, 1-18.

49. Pastén-Zapata, E.; Ledesma-Ruiz, R.; Harter, T.; Ramírez, A.I.; Mahlknecht, J. Assessment of sources and fate of nitrate in shallow groundwater of an agricultural area by using a multi-tracer approach. Sci. Total Environ. 2014, 470-471, 855-864. [CrossRef]

50. Marchitto, T.M. Nutrient Proxies, 2nd ed.; Elsevier B.V.: Amsterdam, The Netherlands, 2013. [CrossRef]

51. Granger, J.; Sigman, D.M.; Needoba, J.A.; Harrison, P.J. Coupled nitrogen and oxygen isotope fractionation of nitrate during assimilation by cultures of marine phytoplankton. Limnol. Oceanogr. 2004, 49, 1763-1773. [CrossRef]

52. Xiaofeng, C.; Liuyan, Y.; Lin, X.; Aijun, M.; Beidou, X. Nitrogen removal by denitrification during cyanobacterial bloom in Lake Taihu. J. Freshw. Eco. 2012, 27, 243-258. [CrossRef]

53. Jiang, W.; Wang, G.; Sheng, Y.; Zhao, D. Enrichment and Sources of Nitrogen in Groundwater in the Turpan-Hami Area, Northwestern China. Expo. Health 2016, 8, 389-400. [CrossRef]

54. Kendall, C.; Elliot, E.M.; Wankel, S.D. Tracing Anthropogenic Inputs of Nitrogen to Ecosystems, 2nd ed.; Blackwell: Hoboken, NJ, USA, 2007; pp. 375-449.

55. Anornu, G.; Gibrilla, A.; Adomako, D. Tracking nitrate sources in groundwater and associated health risk for rural communities in the White Volta River basin of Ghana using isotopic approach ( $815 \mathrm{~N}, 818 \mathrm{O}] \mathrm{NO} 3$ and 3H). Sci. Total Environ. 2017, 603-604, 687-698. [CrossRef]

56. Koba, K.; Tokuchi, N.; Wada, E.; Nakajima, T.; Iwatsubo, G. Intermittent denitrification: The application of a $15 \mathrm{~N}$ natural abundance method to a forested ecosystem. Geochim. Cosmochim. Acta 1997, 61, 5043-5050. [CrossRef]

57. Marchant, H.K.; Ahmerkamp, S.; Lavik, G.; Tegetmeyer, H.E.; Graf, J.; Klatt, J.M.; Holtappels, M.; Walpersdorf, E.; Kuypers, M.M.M. Denitrifying community in coastal sediments performs aerobic and anaerobic respiration simultaneously. ISME J. 2017, 11, 1799-1812. [CrossRef] [PubMed]

58. Sharma, S.K.; Sanghi, R. Wastewater Reuse and Management; Springer: Dordrecht, The Netherlands, 2013. [CrossRef]

59. Piatek, K.B.; Mitchell, M.J.; Silva, S.R.; Kendall, C. Sources of nitrate in snowmelt discharge: Evidence from water chemistry and stable isotopes of nitrate. Water Air Soil Pollut. 2005, 165, 13-35. [CrossRef] 
60. Casciotti, K.L.; Sigman, D.M.; Ward, B.B. Linking diversity and stable isotope fractionation in ammonia-oxidizing bacteria. Geomicrobiol. J. 2003, 20, 335-353. [CrossRef]

61. Kendall, C.; Aravena, R. Nitrate Isotopes in Groundwater Systems. Environ. Tracers Subsurf. Hydro. 2000, 261-297. [CrossRef]

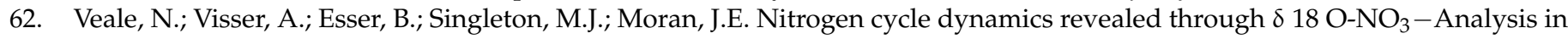
California Groundwater. Geosciences 2019, 9, 95. [CrossRef]

63. Mader, M.; Roberts, A.M.; Porst, D.; Schmidt, C.; Trauth, N.; van-Geldern, R.; Barth, J.A.C. River recharge versus $\mathrm{O}_{2}$ supply from the unsaturated zone in shallow riparian groundwater: A case study from the Selke River (Germany). Sci. Total Environ. 2018, 634, 374-381. [CrossRef]

64. Kendall, C. Tracing Nitrogen Sources and Cycling in Catchments. Elsevier B.V.: Amsterdam, The Netherlands, 1998. [CrossRef]

65. Mayer, B.; Bollwerk, S.M.; Mansfeldt, T.; Hütter, B.; Veizer, J. The oxygen isotope composition of nitrate generated by nitrification in acid forest floors. Geochim. Cosmochim. Acta 2001, 65, 2743-2756. [CrossRef]

66. Shi, J.; Ohte, N.; Tokuchi, N.; Imamura, N.; Nagayama, M.; Oda, T.; Suzuki, M. Nitrate isotopic composition reveals nitrogen deposition and transformation dynamics along the canopy-soil continuum of a suburban forest in Japan. Rapid Commun. Mass Spectro 2014, 28, 2539-2549. [CrossRef]

67. Ogrinc, N.; Tamše, S.; Zavadlav, S.; Vrzel, J.; Jin, L. Evaluation of geochemical processes and nitrate pollution sources at the Ljubljansko polje aquifer (Slovenia): A stable isotope perspective. Sci. Total Environ. 2019, 646, 1588-1600. [CrossRef]

68. Widory, D.; Petelet-Giraud, E.; Négrel, P.; Ladouche, B. Tracking the sources of nitrate in groundwater using coupled nitrogen and boron isotopes: A synthesis. Environ. Sci. Tech. 2005, 39, 539-548. [CrossRef] [PubMed]

69. Bronders, J.; Tirez, K.; Desmet, N.; Widory, D.; Petelet-Giraud, E.; Bregnot, A.; Boeckx, P. Use of Compound-Specific Nitrogen (d 15N), Oxygen (d 18O), and Bulk Boron (d 11B) Isotope Ratios to Identify Sources of Nitrate-Contaminated Waters: A Guideline to Identify Polluters. Environ. Forensics 2012, 13, 32-38. [CrossRef]

70. Saccon, P.; Leis, A.; Marca, A.; Kaiser, J.; Campisi, L.; Böttcher, M.E.; Savarino, J.; Escher, P.; Eisenhauer, A.; Erbland, J. Multiisotope approach for the identification and characterisation of nitrate pollution sources in the Marano lagoon (Italy) and parts of its catchment area. Appl. Geochem. 2013, 34, 75-89. [CrossRef]

71. Vengosh, A.; Kolodny, Y.; Spivack, A.J. Groundwater Pollution Determined by Boron Isotope Systematics; International Atomic Energy Agency: Vienna, Austria, 1998; pp. 17-37.

72. Reed, E.M.; Duranceau, S.J. Chemical and isotopic composition of nitrogen and boron in septic tank wastewater samples. Environ. Earth Sci. 2016, 75, 1-7. [CrossRef]

73. Bassett, R.L. A critical evaluation of the available measurements for the stable isotopes of boron. Appl. Geochem. 1990, 5, 541-554. [CrossRef]

74. Komor, S.C. Boron Contents and Isotopic Compositions of Hog Manure, Selected Fertilizers, and Water in Minnesota. J. Environ. Qual. 1997, 26, 1212-1222. [CrossRef]

75. Tirez, K.; Brusten, W.; Widory, D.; Petelet, E.; Bregnot, A.; Xue, D.; Boeckx, P.; Bronders, J. Boron isotope ratio ( $\delta 11 B)$ measurements in Water Framework Directive monitoring programs: Comparison between double focusing sector field ICP and thermal ionization mass spectrometry. J. Anal. At. Spectrom. 2010, 25, 964-974. [CrossRef]

76. Barth, S. Application of boron isotopes for tracing sources of anthropogenic contamination in groundwater. Water Res. 1998, 32, 685-690. [CrossRef]

77. Puig, R.; Soler, A.; Widory, D.; Mas-Pla, J.; Domènech, C.; Otero, N. Characterizing sources and natural attenuation of nitrate contamination in the Baix Ter aquifer system (NE Spain) using a multi-isotope approach. Sci. Total Environ. 2017, 580, 518-532. [CrossRef]

78. Fernandes, P.; Carvalho, M.R.; Silva, M.C.; Rebelo, A.; Zeferino, J. Application of nitrogen and boron isotopes for tracing sources of anthropogenic contamination in Monforte-Alter do Chão aquifer system, Portugal. Sustain. Water Resour. Manag. 2019, 5 , 249-266. [CrossRef]

79. Wahl, E.H.; Fidric, B.; Rella, C.W.; Koulikov, S.; Kharlamov, B.; Tan, S.; Kachanov, A.A.; Richman, B.A.; Crosson, E.R.; Paldus, B.A.; et al. Applications of cavity ring-down spectroscopy to high precision isotope ratio measurement of $13 \mathrm{C} / 12 \mathrm{C}$ in carbon dioxide. Isot. Environ. Health Stud. 2006, 42, 21-35. [CrossRef] [PubMed]

80. Pierchala, A.; Rozanski, K.; Dulinski, M.; Gorczyca, Z.; Marzec, M.; Czub, R. High-precision measurements of $\delta 2 \mathrm{H}, \delta 18 \mathrm{O}$ and $\delta$ $17 \mathrm{O}$ in water with the aid of cavity ring-down laser spectroscopy. Isot. Environ. Health Stud. 2019, 55, 290-307. [CrossRef]

81. Balslev-Clausen, D.; Dahl, T.W.; Saadd, N.; Rosinga, M.T. Precise and accurate d13C analysis of rock samples using Flash Combustion-Cavity Ring Down Laser Spectroscopy. J. Anal. At. Spectrom. 2013, 28, 413-614. [CrossRef]

82. Wang, C. Plasma-cavity ringdown spectroscopy (P-CRDS) for elemental and isotopic measurements. J. Anal. At. Spectrom. 2007, 22, 1337-1436. [CrossRef]

83. Chen, T.; Ober, D.C.; Miri, R.; Bui, T.Q.; Shen, L.; Okumura, M. Optically switched dual-wavelength cavity ring-down spectrometer for high-precision isotope ratio measurements of methane $\delta \mathrm{d}$ in the near infrared. Anal. Chem. 2021, 93, 6375-6384. [CrossRef] [PubMed]

84. Jung, H.; Koh, D.; Kim, Y.S.; Jeen, S.; Lee, J. Stable isotopes of water and nitrate for the identification of groundwater flowpaths: A Review. Water 2020, 12, 138. [CrossRef] 
85. Sigman, D.M.; Casciotti, K.L.; Andreani, M.; Barford, C.; Galanter, M.; Bo, J.K.; Supe, Ä.N. A Bacterial Method for the Nitrogen Isotopic Analysis of Nitrate in Seawater and Freshwater. Anal. Chem. 2001, 73, 4145-4153. [CrossRef]

86. Dotsika, E.; Poutoukis, D.; Kloppmann, W.; Guerrot, C.; Voutsa, D.; Kouimtzis, T.H. The use of O, H, B, Sr and S isotopes for tracing the origin of dissolved boron in groundwater in Central Macedonia, Greece. Appl. Geochem. 2010, 25, $1783-1796$. [CrossRef] 